\title{
Confirmatory Chemical Analyses and Solid Phase Bioassays on Sediment From the Columbia River Estuary at Tongue Point, Oregon
}
J. S. Young
M. E. Barrows
J. Q. Word
V. I. Cullinan
C. W. Apts
N. P. Kohn
Battelle/Marine Sciences Laboratory
Sequim, Washington

December 1988

Prepared for the

U.S. Army Corps of Engineers

Portland District

under a Related Services Agreement

with the U.S. Department of Energy

Contract DE-AC06-76RLO 1830

Pacific Northwest Laboratory

Operated for the U.S. Department of Energy

by Battelle Memorial Institute 


\title{
DISCLAIMER
}

This report was prepared as an account of work sponsored by an agency of the United States Government. Neither the United States Government nor any agency thereof, nor Battelle Memorial Institute, nor any or their employees, makes any watranty, expressed or implied, or assumes any legal liability or responsibility for the accuracy, completeness, or usefulness of any information, apparatus, product, or process disclosed, or represents that its use would not infringe privately owned rights. Reference herein to any specific commercial product, process, or service by trade name, trademark, manufacturer, or otherwise dow:s not necessarily constitute or imply its endorsement, recommendation, or favoring by the United States Government or any agency thereof, or Battelle Memorial Institute. The views and opinions of authors expressed herein do not necessarily state or reflect those of the United States Government or any agency thereof.

\author{
PACIFIC NORTHWEST LABORATORY \\ operated by \\ BATTELLE MEMORIAL INSTITUTE \\ for the \\ UNITED STATES DEPARTMENT OF ENERGY \\ under Contract DE-ACO6-76RLO 1830
}

\begin{tabular}{|c|c|}
\hline \multicolumn{2}{|c|}{ Printed in the United States of America } \\
\hline \multicolumn{2}{|c|}{ Avallable from } \\
\hline \multicolumn{2}{|c|}{ National Technical Information Service } \\
\hline \multicolumn{2}{|c|}{ United States Department of Commerce } \\
\hline \multicolumn{2}{|c|}{5285 Porl Royal Road } \\
\hline \multicolumn{2}{|c|}{ Springfield, Virginia 22161} \\
\hline \multirow{2}{*}{\multicolumn{2}{|c|}{$\begin{array}{l}\text { NTIS Price Codes } \\
\text { Microfiche A01 }\end{array}$}} \\
\hline & \\
\hline \multicolumn{2}{|c|}{ Printed Copy } \\
\hline & Price \\
\hline Pages & Cades \\
\hline 001.025 & $\mathrm{~A} 02$ \\
\hline $026-050$ & $\mathrm{~A} 03$ \\
\hline $051-075$ & A04 \\
\hline $076-100$ & A05 \\
\hline $101 \cdot 725$ & $\mathrm{~A} 06$ \\
\hline $126-150$ & $\mathrm{~A} 0 \mathrm{7}$ \\
\hline $151-175$ & $\mathrm{~A} 08$ \\
\hline $176-200$ & $A 09$ \\
\hline $201-225$ & A10 \\
\hline $226-250$ & A11 \\
\hline $251-275$ & A 12 \\
\hline $276-300$ & A13 \\
\hline
\end{tabular}


CONFIRMATORY CHEMICAL ANALYSES AND SOLID-PHASE BIOASSAYS ON SEDIMENT FROM THE COLUMBIA RIVER ESTUARY AT TONGUE POINT, OREGON
J. S. Young
M. E. Barrows (a)
J. Q. Word
V. I. Cullinan
C. W. Apts
N. P. Kohn

Battelle/Marine Sciences Laboratory Sequim, Washington

December 1988

Prepared for the U.S. Army Corps of Engineers Portland District under a Related Services Agreement with the U.S. Department of Energy under Contract DE-AC06-76RLO 1830

Pacific Northwest Laboratory Richland, Washington 99352

(a) 27 Compass Circle Hyannis, Massachusetts 


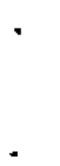




\section{SUMMARY}

The Department of Economic Development, Ports Division, of the state of Oregon plans to develop a former ship suppiy and storage site near Tongue Point, Oregon, for commercial shipping. The development wouid require dredging the adjacent waterway to the Columbia River 40 -foot channel to admit commercial vessels. The Portland District of the U.S. Army Corps of Engineers requested the Battelle/Marine Sciences Laboratory (MSL) to conduct confirmatory solid-phase bioassays that would provide technical data for an evaiuation of the potential environmental impact of ocean disposal of the dredged material. These confirmatory studies provided chemical and biological information required by ocean dumping regulations to determine suitability of Tongue Point sediments for ocean disposai.

Sediment core samples were collected from Cathlamet Bay at Tongue Point in the upper Columbia River estuary. Sediment surface grab samples were collected at reference/control sites offshore from the mouth of the Columbia River (Disposal Site F) and at West Beach, Whidbey Is1and, Washington. The Tongue Point sediments were mixed into two composited batches. The MSL conducted solid-phase bioassays with these composites and reference sediments on four species of organisms.

Four survivat tests were conducted during a 10-day, solid-phase bioassay. Clams (Macoma nasuta) and polychaetes (Nephtys caecoides) were exposed to the two composites of test sediments from Tongue Point and the reference sediment from Disposal Site F. M. nasuta was subjected to the same treatments for 20 days to examine both survival and bioaccumulation. Amphipods (Grandidierella japonica) and (Rhepoxynius abronius) were exposed 10 days to the same treatments plus the habitat sediment of $\underline{R}$. abronius. The sediment treatments were chemically analyzed for 8 metals or metalloids, 65 polynuclear aromatic hydrocarbons, 19 pesticides, 5 polychlorinated biphenyls, and 5 conventional contaminants. The sediments were also physically analyzed for grain size. Bioaccumulation of chemical contaminants that were eievated in sediments was then measured in the tissues of clams exposed to treatments for 20 days. 
These confirmatory tests revealed elevated concentrations of some contaminants in the Tongue Point sediment. All solid-phase bioassays had less than $10 \%$ mortality in both reference and control sediments, which makes all tests valid. The bioassays under static and flow-through conditions resulted in no statistically significant difference in survival among treatments for three of the four test species. Only one test (․․ abronius, static) had survival in test sediments significantiy different from controls. In that test more than $10 \%$ of the amphipods died in the test sediment; however, survival ranged from 60 to $95 \%$ among the replicates of the two composites. This indicates a possible patchiness to the sediment toxicity even though the composites appeared homogeneous. The flow-through bioassay for $\underline{R}$. abronius, which is more representative of environmental conditions at the ocean disposal site, showed no significant differences in survival. Actual disposal of Tongue Point sediment in the ocean will probably result in dilution of contaminants by flowing seawater during and after its descent to the sea floor, thereby minimizing acuteily toxic effects.

Those chemicals that had elevated concentrations in sediments were also evaluated for bioaccumulation. A significant enfiancement of $4,4^{\prime}$-DDD, a degradation product of DDT, was seen in the tissues of clams at an average concentration of $8.0 \mathrm{\mu g} / \mathrm{Kg}$ (wet weight). Allowatile 1 imits for interstate commerce established by the U.S. Food and Drug Acministration are $5000 \mu \mathrm{g} / \mathrm{kg}$ (wet weight), or a factor of 625-fold the concentration measured in the clams. No other chemicals were bioaccumulated. 


\section{CONTENTS}

SUMMARY

1.0 INTRODUCTION . . . . . . . . . . . . . . . . . . . . . 1.1

2.0 MATERIALS AND METHODS . . . . . . . . . . . . . . . . . . 2.1

2.1 STUDY AREA DESCRIPTION . . . . . . . . . . . . . . 2.1

2.2 SEDIMENT SAMPLE COLLECTION AND PRESERVATION . . . . . . . . 2.4

2.2.1 Vessels and Navigation ............ 2.4

2.2.2 Sampling Equipment, Sampling Methods, Field

Collections............... . . . 2.6

2.3 SAMPLE PREPARATION PROCEDURES . . . . . . . . . . . . 2.7

2.3.1 Labware Cleaning . . . . . . . . . . . . . 2.7

2.3.2 Solid-Phase Sample Preparation . . . . . . . . 2.7

2.4 CHEMICAL ANALYTICAL PROCEDURES . . . . . . . . . . . . . . . 2.8

2.4.1 Priority Pollutant Polynuclear Aromatic Hydrocarbons (PAHs), Pesticides, and Polychlorinated Biphenyls (PCBs) .................. . . . 2.8

2.4.2 Metals and Metalloids . . . . . . . . . . 2.8

2.4.3 Total Organic Carbons . . . . . . . . . . . . 2.9

2.4.4 $0 i 1$ and Grease . . . . . . . . . . . . . . 2.9

2.4.5 Petroleum Hydrocarbons . . . . . . . . . . 2.10

2.4.6 Dissolved Sulfides . . . . . . . . . . . . 2.10

2.4.7 Ammonia Nitrogen ................. 2.11

2.4.8 Grain Size................. 2. 2.11

2.5 TOXICOLOGICAL TESTING PROCEDURES . . . . . . . . . . . 2.12

2.5.1 Solid-Phase Tests.............. . 2.12

2.5.2 Bioaccumulation Measurements . . . . . . . . 2.19 
2.6 QUALITY ASSURANCE/QUALITY CONTROL PROCEDURES . . . . . . 2.19

2.6.1 Sediment Sampling, Storage, and Tracking . . . . 2.20

2.6.2 Biological Testing ........... 2.20

2.6.3 Chemical Testing ............. 2.21

2.7 STATISTICAL DESIGN, DATA ANALYSIS, AND INTERPRETATION . . 2.22

2.7.1 Randomization . . . . . . . . . . 2.22

2.7 .2 Solid-Phase Bioassays . . . . . . . . . 2.22

3.0 RESULTS AND DISCUSSION . . . . . . . . . . . . . . 3.1

3.1 SOLID-PHASE TESTS . . . . . . . . . . . . . 3.1

3.1 .1 Poilychaetes and $\mathrm{Clams} \ldots \ldots . . . \ldots 3 . . . \ldots$

3.1 .2 Amphipods ............... . . 3.3

3.2 CHEMICAL ANALYSIS OF DREDGED-MATERIAL SAMPLES . . . . . 3.8

3.2.1 Priority Pollutant Polynuclear Aromatic Hydrocarbons (PAHs), Pesticides, and Polychlorinated Biphenyls

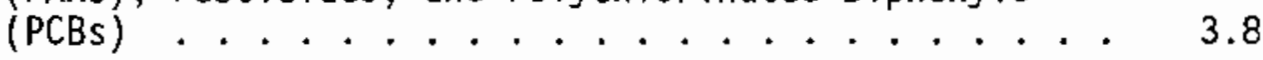

3.2.2 Metals and Metalloids. . . . . . . . . . . 3.9

3.2.3 Total Organic Carbon ............ 3.11

3.2 .4011 and Grease ......................... 3.11

3.2.5 Petroleum Hydrocarbons ........... 3.11

3.2.6 Dissolved Sulfides and Ammonia ........ 3.12

3.2.7 Grain Size and Total Solids .......... . 3.12

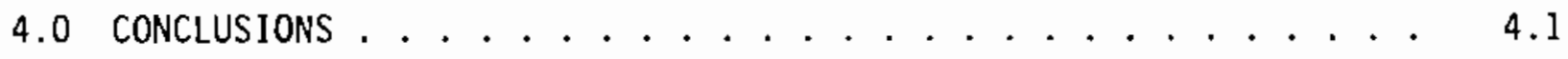

4.1 SOLID-PHASE BIOASSAYS . . . . . . . . . . 4.1

4.2 CHEMICAL TRENDS . . . . . . . . . . . . . . 4.2

4.3 BIOACCUMULATION $\ldots \ldots \ldots \ldots . \ldots . \ldots . \ldots . \ldots . \ldots$

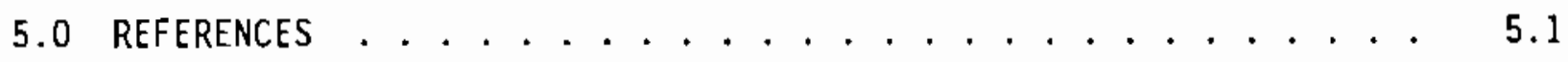

APPENDIX A - SAMPLING AND SAMPLE COMPOSITE INFORMATION . . . . . A.I 
APPENDIX B - SEDIMENT PHYSICAL AND CHEMICAL DATA SUMMARY . . . . . B.I
APPENDIX C - TISSUE CHEMISTRY DATA SUMMARY . . . . . . . . . . C.1
APPENDIX D - CALIBRATION SCHEDULES . . . . . . . . . . . . . D. 


\section{FIGURES}

2.1 Tongue Point Station Locations . . . . . . . . . 2.2

2.2 Location of Ocean Disposal Site $F$ off the Columbia River

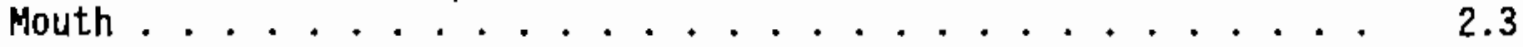

2.3 Aquarium Arrangement for Bioassays ........... 2.13

2.4 Bioassay Test Equipment . . . . . . . . . . . . 2.14

$3.195 \%$ Confidence Intervals About the True Angular Transformed

Means of R. abronius Surviving the 10-Day Static Exposure . . . . 3.6 


\section{TABLES}

2.1 Volume of Sediment Required for Analyses Performed on

Sediment Treatments ................. 2.4

2.2 Summary of Experimental Characteristics of Solid-Phase

Bioassays and Bioaccumulation Tests Both Flow-Through

and Static ..................... 2.4

2.3 Sample Stations and Coring Times at Tongue Point

on August 23, $1988 \ldots \ldots . \ldots . . \ldots 2 . \ldots$

2.4 Positions and Depths of Grabs Prior to Anchoring

in Disposal Site F . . . . . . . . . . . . 2.6

2.5 Size Fractions of Sediment Grain Size Measured by Wet

Sieving of Sediment or Through Pipette Techniques . . . . . . 2.11

3.1 Number of Test Animals Alive at the End of the

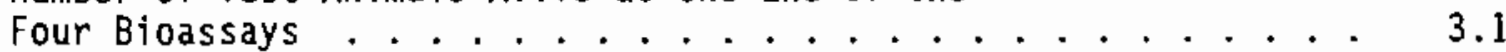

3.2 Proportion of Polychaetes Surviving After 10-Day Exposure to Three Sediment Treatments and Comparison of the Means . . . . . 3.2

3.3 Balanced One-Way ANOVA for Three Sediment Treatments Using the Arc Sine Square Root of the Proportion of $\underline{\mathbf{N}}$. caecoides Surviving a 10-Day, Solid-Phase Exposure .............

3.4 Proportion of Clams Surviving After 20-Day Exposure to Three Sediment Treatments and Comparison of the Means . . . . . . 3.3

3.5 Balanced One-Way ANOVA for Three Sediment Treatments Using the Arc Sine Square Root of the Proportion of M. nasuta Surviving a 20-Day, Solid-Phase Exposure ............

3.6 Proportion of Amphipods Surviving After 10-Day Flow-Through Exposure to Four Sediment Treatments and Comparison

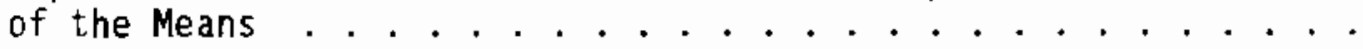

3.7 Balanced One-Way ANOVA for Four Sediment Treatments Using the Arc Sine Square Root of the Proportion of $\underline{R}$. abronius Surviving a 10-Day, Solid-Phase, Flow-Through Exposure .......

3.8 Proportion of Amphipods Surviving After 10-Day Static Exposure to Four Sediment Treatments and Comparison of the Means.... 3.5

3.9 Balanced One-Way ANOVA for Three Sediment Treatments Using the Arc Sine Square Root of the Proportion of $\underline{R}$. abronius Surviving a 10-Day, Solid-Phase Static Exposure 
3.10 Proportion of Amphipods Surviving After 10-Day Flow-Through Exposure to Four Sediment Treatments and Comparison

3.11 Proportion of Amphipods Surviving After 10-[lay Static Exposure to Four Sediment Treatments and Comparison of the Means ................... 3.7

3.12 Balanced One-Way ANOVA for Four Sediment Treatments Using the Arc Sine Square Root of the Proportion of $\underline{G}$. japonica Surviving

3.13 Balanced One-Way ANOVA for Four Sediment Treatments Using the Arc Sine Square Root of the Proportion of G. japonica Surviving a 10-Day, Solid-Phase, Flow-Through Exposure

3.14 Polynuclear Aromatic Hydrocarbons, Phthalates, and Pesticides Detected or Considered Present in Tongue Point Composited Sediments . . . . . . . . . . . . . . . .

3.15 Concentrations of Metals in the Four Sediment Treatments and Average Crustal Abundance of Metals in Shaie and Basalt Soils Throughout the World . . . . . . . . . . . . .

3.16 Comparison of Metal Concentration for Each Sediment Treatment Relative to Metal Concentration at the Reference Site ..... 3.1I

3.17 Comparison of Metal Concentration for Each Sediment Treatment Relative to Metal Concentration at the Reference Site ..... 3.11

3. I8 Concentration and Enrichment Factors of TOC from Tongue Point Disposal Site $F$ and West Beach ............. 3.12

3.19 Conventionals/Petroleum Hydrocarbons in Sediments, dry wt . . 3.12

3.20 Sediment Grain Size and Total Solids . . . . . . . . . . 3.13

4.I Significant Differences in Survival Among Bioassay Treatments

4.2 Summary of Sediment Characterization and Contaminant Enrichment in Tongue Point Sediments Relative to Reference Sediments ... 


\subsection{INTRODUCTION}

Tongue Point, on the eastern edge of Astoria, Oregon, extends northward into the Columbia River. Mott Basin, on the eastern side of Tongue Point, was used by the U.S. Navy and the Marine Maritime Comission during and after the Second World War for supplying ships and for ship storage. The site has been inactive since the early 1950s. The Oregon State Department of Economic Development, Ports Division, wants to develop the area for commercial shipping, such as an automobile import receiving facility, which will require deepening of the waterway. The proposed depth of the channel will be 30 feet and the turning basin 25 feet. Because of the past use of Mott Basin, there are concerns that dredging will introduce unknown contaminants into whatever disposal area is selected.

Section 103 of the Marine Protection, Research, and Sanctuaries Act of 1972 (Public Law 92-532) mandates that all proposed operations involving the disposal of dredged materials into ocean waters be evaluated to determine potential environmental impact. These evaluations are conducted jointly by the U.S. Army Corps of Engineers (USACE) and the U.S. Environmental Protection Agency (EPA) and must be performed according to criteria published in the Federal Reqister (1977), which emphasize using bioassays or other empirical techniques to provide direct measurement of potential ecological effects. The reguiations specificaliy require USACE to address sediment quality issues in these evaluations so that appropriate certifications from state agencies and disposal site approval from the EPA can be obtained.

The USACE contracted with Battelle/Marine Sciences Laboratory (MSL) ${ }^{(a)}$ to conduct studies to provide the technical data supporting an evaluation of the potential environmental impact of this dredging and disposal project. The purpose of the studies was to provide biological and chemical information required by ocean dumping regulations to determine the suitability of the Tongue Point site sediments for ocean disposal. The studies included chemica? anatyses of selected contaminants in sediment and confirmatory solid-phase

(a) The Marine Sciences Laboratory is a component of the Pacific Northwest Laboratory which is operated for the U.S. Department of Energy by Battelle Memorial Institute under Contract DE-AC06-76RLO 1830. 
bioassays performed on four sensitive marine species. Bioaccumulation measurements were made on $\mathrm{clam}$ tissue from individuals surviving 20-day exposure to test sediment. Compounds analyzed were those that had been shown to be elevated in the sediment anaiyses.

To ensure that results of the current study comply with Federal Register requirements, the technical design and procedures were based on guidelines and recommendations provided in the Implementation Manual for Ecological Evaluation of Proposed Discharge of Dredged Material Into Ocean Waters (EPA/USACE 1977) (a).

Section 2.0 of this report describes field and laboratory methods, including quality assurance (QA) and quality control (QC) procedures. Results of chemical analyses, bioassays, and bioaccumulation measurements are provided in Section 3.0. Conclusions on the potential ecclogical impact of the proposed dredging and disposal operations are included in Section 4.0.

(a) A7though this manual is currently being rev'sed, the new version was not available for use at the time of this study. 


\subsection{MATERIALS AND METHODS}

Section 2.1 of this report describes the sampling areas near Tongue Point and offsite Disposal Site $F$ near the mouth of the Columbia River. The biological and chemical tests performed on the sediment are also described in this section. Sample collection and preservation methods are explained in Section 2.2. Section 2.3 describes the preparation of the solid-phase test materials. Chemical analytical procedures are presented in Section 2.4. The test objectives, overall experimental design, and collection and handling of organisms are included in Section 2.5, which also describes methods for bioaccumulation measurements and for the solid-phase bioassays performed on polychaetes (Nephtys caecoides), clams (Macoma nasuta), and amphipods (Grandidierella japonica and Rhepoxynius abronius). Section 2.6 outlines the quality assurance $(Q A)$ and quality control (QC) procedures followed for each of the tests. The statistical design, analysis, and interpretation methods for the study are included in Section 2.7.

\subsection{STUDY AREA DESCRIPTION}

The Tongue Point navigation project is located near the southern shore of the Columbia River between Tongue Point and Mott Island, just east of Astoria, Oregon. Figure 2.1 shows Stations 3, 4, 5, 6, and 7 near the ends of piers 3 through 8 , designated by the USACE for test sediment sample collection.

Stations 1, 2, and 8, used in a previous study, were found to have low levels of contamination, so these were excluded from the present study. For testing, composites were made from Stations 6 and 7 (Composite 1, 1isted in the text at C1) and from Stations 3, 4, and 5 (Composite 2, or C2).

The USACE also identified stations for reference sediment collection off the mouth of the Columbia River at Disposal Site $F$ (Figure 2.2). A second reference sediment, the habitat sediment of $\underline{\mathrm{R}}$. abronius, was collected from West Beach on Whidbey Island, Washington, for use in the amphipod bioassays. The two composite sediments and two reference sediments were used in various chemical analyses and solid-phase bioassays. Specific analyses conducted on each treatment and the required sediment volume for the analyses are provided 


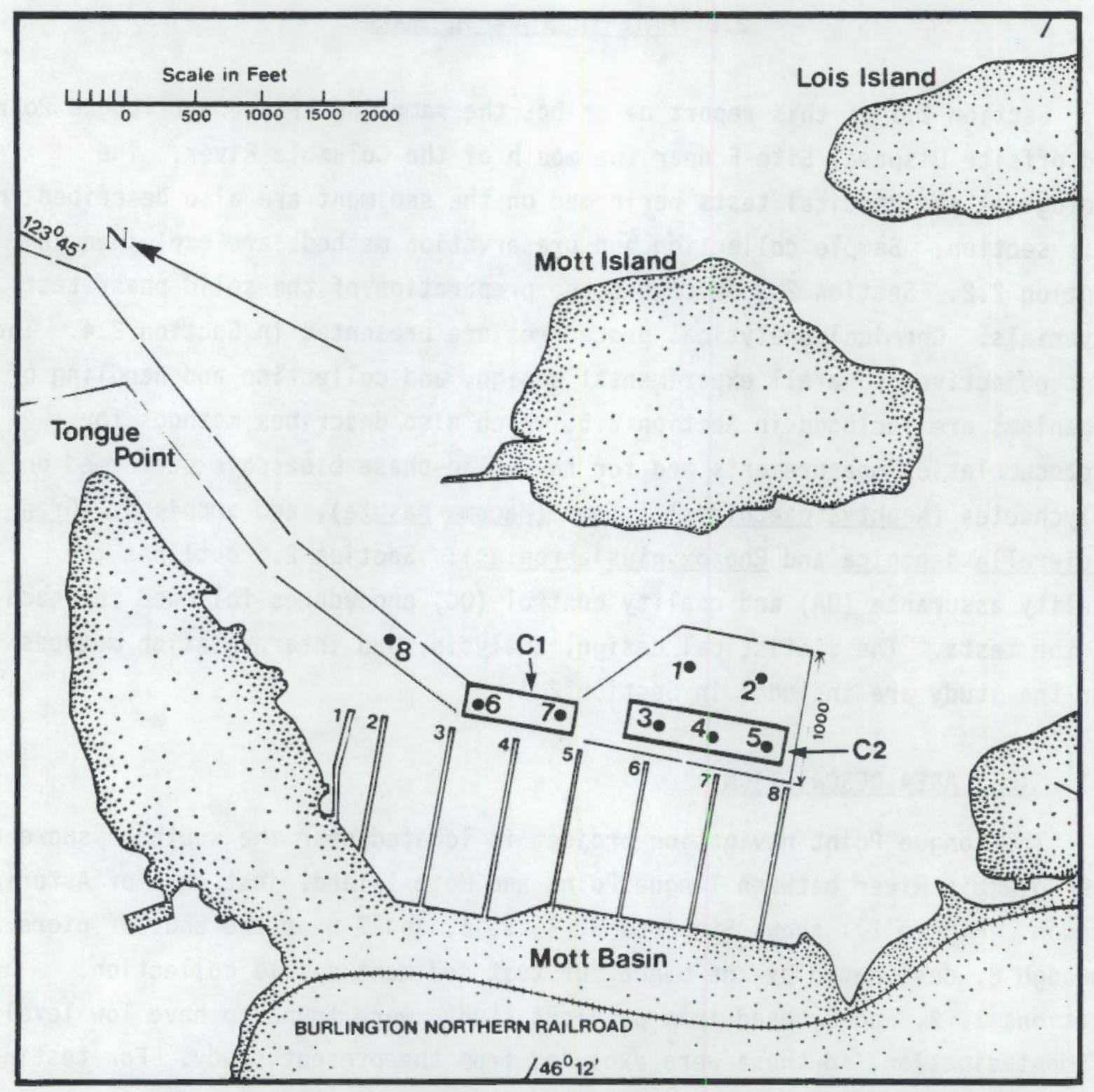

FIGURE 2.1. Tongue Point Station Locations

in Table 2.1. A summary of the experimental design for the solid-phase bioassays and bioaccumulation tests is included in Table 2.2. Details of sampling procedures and individual sample characteristics are provided in Section 2.2. 


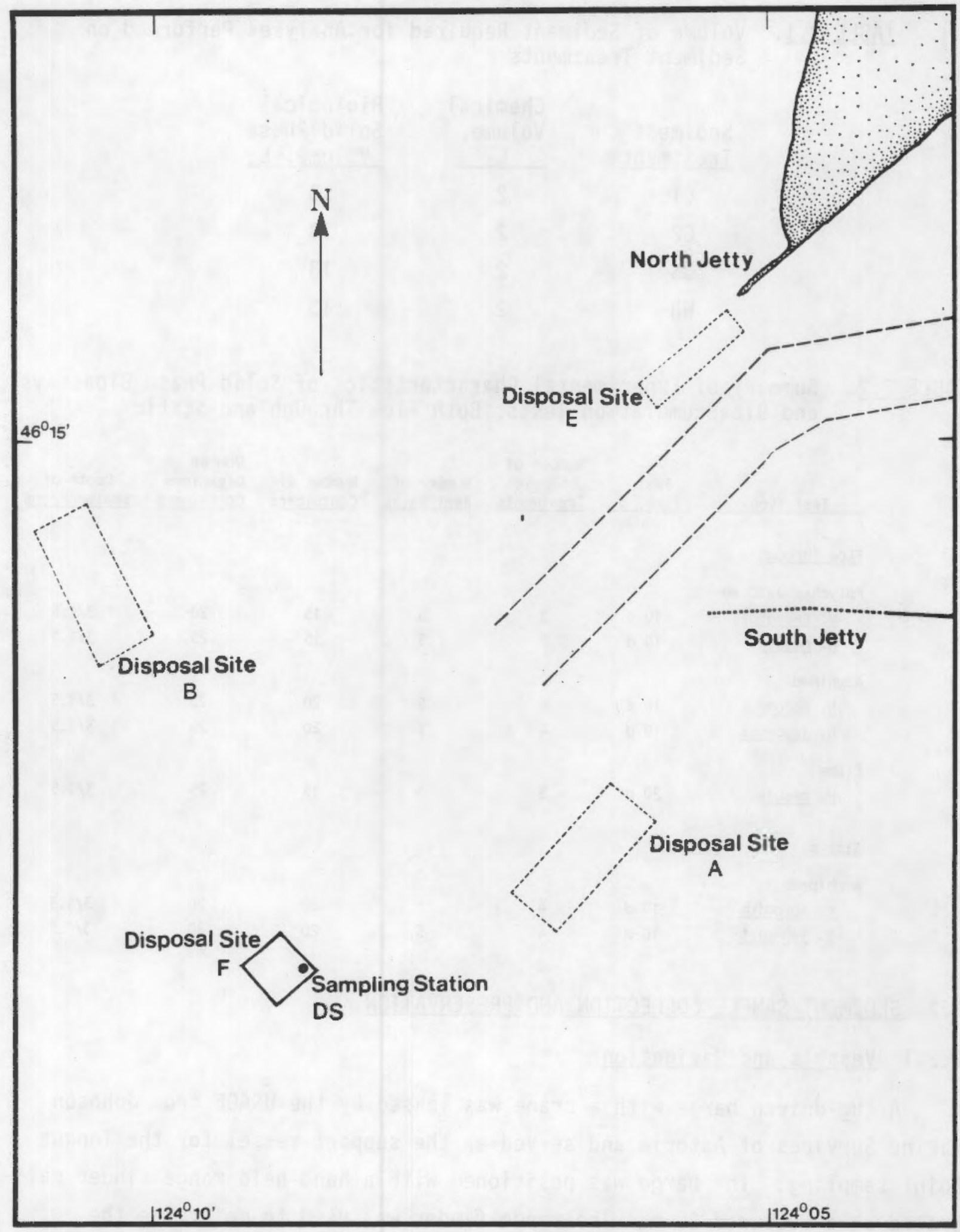

FIGURE 2.2. Location of Ocean Disposal Site $\mathrm{F}$ off the Columbia River Mouth 
TABLE 2.1. Volume of Sediment Required for Analyses Performed on Sediment Treatments

$\begin{array}{cccc}\begin{array}{c}\text { Sediment } \\ \text { Ireatment }\end{array} & & \begin{array}{c}\text { Chemical } \\ \text { Volume, } \\ \text { L }\end{array} & \begin{array}{c}\text { Biological } \\ \text { Solid-Phase } \\ \text { Volume, L }\end{array} \\ \text { C1 } & & 2 & 13 \\ \text { C2 } & 2 & 13 \\ \text { DS } & 2 & 13 \\ \text { WB } & 2 & 13\end{array}$

TABLE 2.2. Summary of Experimental Characteristics of Solid-Phase Bioassays and Bioaccumulation Tests, Both Flow-Through and Static

\begin{tabular}{|c|c|c|c|c|c|c|}
\hline Test Type & $\begin{array}{l}\text { Test } \\
\text { Time, d } \\
\end{array}$ & $\begin{array}{c}\text { Number of } \\
\text { Sample } \\
\text { Treatments }\end{array}$ & $\begin{array}{l}\text { Number of } \\
\text { Repl icates }\end{array}$ & $\begin{array}{l}\text { Number of } \\
\text { Containers }\end{array}$ & $\begin{array}{l}\text { Number of } \\
\text { Organisms } \\
\text { Containers }\end{array}$ & $\begin{array}{c}\text { Depth of } \\
\text { Sediment. cm }\end{array}$ \\
\hline \multicolumn{7}{|l|}{ Flow-Through } \\
\hline \multicolumn{7}{|l|}{ Polychaetes/Clams } \\
\hline N. caecoides & $10 \mathrm{~d}$ & 3 & 5 & 15 & 20 & $3 / 1.5$ \\
\hline M. nasuta & $10 d$ & 3 & 5 & 15 & 25 & $3 / 1.5$ \\
\hline \multicolumn{7}{|l|}{ Amph ipods } \\
\hline R. abronius & $10 \mathrm{~d}$ & 4 & 5 & 20 & 20 & $3 / 1.5$ \\
\hline G. japonica & $10 \mathrm{~d}$ & 4 & 5 & 20 & 20 & $3 / 1.5$ \\
\hline \multicolumn{7}{|l|}{ Clams } \\
\hline ‥ nasuta & $20 d$ & 3 & 5 & 15 & 25 & $3 / 1.5$ \\
\hline \multicolumn{7}{|l|}{$\underline{\text { Static }}$} \\
\hline \multicolumn{7}{|l|}{ Amphipods } \\
\hline R. abronius & $10 d$ & 4 & 5 & 20 & 20 & $3 / 1.5$ \\
\hline G. japonica & $10 d$ & 4 & 5 & 20 & 20 & $3 / 1.5$ \\
\hline
\end{tabular}

\subsection{SEDIMENT SAMPLE COLLECTION AND PRESERVATION}

\subsubsection{Vessels and Navigation}

A tug-driven barge with a crane was leased by the USACE from Johnson Marine Services of Astoria and served as the support vessel for the Tongue Point sampling. The barge was positioned with a hand-held range finder calibrated at a measured $20 \mathrm{~m}$. The range finder was used to determine the 
distance of the stations relative to the ends of the piers. Station positions were held by barge spuds lowered to the bottom. Table 2.3 lists the position of each station.

Operations at Disposal Site $F$ used the R/V Sea Otter, a $58-\mathrm{ft}$ vessel owned by the National Marine Fisheries Service and equipped with winches and a davit. The offshore reference station was located by Loran $C$ and water depth and was held for most of the operation by anchoring.

Collections at West Beach used a $25-\mathrm{ft}$ vessel owned by MSL. Station positioning was accomplished by range fixes to reference landmarks, water depth, and the presence of amphipods. This station is routinely occupied by MSL staff.

IABLE 2.3. Sampling Stations and Coring Times at Tongue Point on August 23, 1988

\begin{tabular}{|c|c|c|c|c|c|}
\hline Station & Position & $\begin{array}{c}\text { Water } \\
\text { Depth, m }\end{array}$ & $\begin{array}{c}\text { Core } \\
\text { Number }\end{array}$ & Time & $\begin{array}{l}\text { Penetration } \\
\text { Depth, ft }\end{array}$ \\
\hline 6 & $\begin{array}{l}65 \mathrm{~m} \text { SE of } \\
\text { third pier }(\mathrm{a})\end{array}$ & 6.0 & $\begin{array}{l}1 \\
2 \\
3 \\
4\end{array}$ & $\begin{array}{l}1209 \\
1253 \\
1306 \\
1315\end{array}$ & $\begin{array}{l}6.0 \\
7.0 \\
7.5 \\
6.5\end{array}$ \\
\hline 7 & $\begin{array}{l}65 \mathrm{~m} N / N E \text { of } \\
\text { fifth pier }\end{array}$ & 6.0 & $\begin{array}{l}1 \\
2 \\
3 \\
4\end{array}$ & $\begin{array}{l}1336 \\
1340 \\
1347 \\
1348\end{array}$ & $\begin{array}{l}6.5 \\
5.5 \\
5.5 \\
5.5\end{array}$ \\
\hline 3 & $\begin{array}{l}65 \mathrm{~m} E \text { of } \\
\text { sixth pier }\end{array}$ & 5.71 & $\begin{array}{l}1 \\
2 \\
3\end{array}$ & $\begin{array}{l}1415 \\
1421 \\
1426\end{array}$ & $\begin{array}{l}6.0 \\
6.0 \\
6.0\end{array}$ \\
\hline 4 & $\begin{array}{l}62 \mathrm{~m} \mathrm{E} \\
\text { north corner } \\
\text { of seventh pier }\end{array}$ & 5.0 & $\begin{array}{l}1 \\
2\end{array}$ & $\begin{array}{l}1426 \\
1445\end{array}$ & $\begin{array}{l}6.0 \\
6.0\end{array}$ \\
\hline 5 & $\begin{array}{l}63 \mathrm{~m} \mathrm{~N} / \mathrm{NE} \text { of } \\
\text { eighth pier }\end{array}$ & 4.4 & $\begin{array}{l}1 \\
2\end{array}$ & $\begin{array}{l}1530 \\
1537\end{array}$ & $\begin{array}{l}6.0 \\
7.0\end{array}$ \\
\hline
\end{tabular}

(a) Third pier from north. 


\subsubsection{Sampling Equipment, Sampling Methods, Field Collections}

Cores were collected at Tongue Point on August 23, 1988, with a 2-in. inside diameter vibra corer (Vi-Cor, Inc., Everett, Washington) with 5-ft, acid-cleaned, cellulose acetate butyrate core liners. Table 2.31 ists the water depth at each station, the number of cores taken, times, and the depth the core barrel had to penetrate to obtain a full core. All cores contained $5 \mathrm{ft}$ of sediment. Any core with less than that amount was rejected. Cores were capped, labeled, and stored in a refrigerator van at approximately $4^{\circ} \mathrm{C}$.

Sediments from Disposal Site F were collected on August 25, 1988, using a $0.1-m^{2}$ stainless steel modified van Veen grab. Five grabs were taken while the boat was drifting over the reference site; Table 2.4 lists the Loran $C$ positions of each. The drift was fast, which resulted in an acute wire angle and made grabbing difficult, so the remaining grabs were collected after the boat was anchored. The sediments were stored in insulated coolers. Both cores and coolers were transported to MSL in a refrigerated truck. Upon arrival, all samples were logged by a sample custodian according to custody procedures found below in Section 2.6.1.

A sma11, stainless steel epibenthic sled was used to collect both sediment and amphipods at West Beach on August 25. This dredge sampled sediment to a depth of $7 \mathrm{~cm}$ over approximately $10 \mathrm{~m}$ of drift. This technique avoids damaging collected organisms. The collected material and organisms were transferred directly into clean coolers. These coolers were transported to MSL the same day collected.

\section{TABLE 2.4. Positions and Depths of Grabs Prior to Anchoring in Disposal Site $F(a)$}

\begin{tabular}{|c|c|c|c|}
\hline Grab & Loran C & Readings & Water Depth, ft \\
\hline 1 & 12108.0 & 28023.5 & 131 \\
\hline 6 & 12108.1 & 28023.5 & 129 \\
\hline 12 & 12107.6 & 28023.9 & 128 \\
\hline 13 & 12107.6 & 28023.9 & 128 \\
\hline 17 & 12107.6 & 28023.9 & 130 \\
\hline
\end{tabular}

(a) Anchored position was 121076280238 at $128 \mathrm{ft}$. 


\subsection{SAMPLE PREPARATION PROCEDURES}

\subsubsection{Labware Cleaning}

All labware was washed in a Forma laboratory dishwasher with Forma Soap Solution 2, followed by three continuous rinse cycles with double-distilled water and hot air drying. After this process was completed, labware was soaked in a solution of $2 \%$ nitric acid ( $\mathrm{HNO}_{3}$, Baker Instra-analyzed grade) for at least $4 \mathrm{~h}$. The labware was rinsed five times with double-distilled water, three times with methylene chloride, and then air dried under a laboratory hood:

The 10- and 55-gal, a11-glass aquaria that were used in the bioassays or contained sediment were too large to be cleaned in the dishwasher, so they were washed by hand with hot soapy water and rinsed with tap water a minimum of five times. The containers were then partially filled with deionized water with an amount of concentrated $\mathrm{HNO}_{3}$ added to provide a $2 \%$ acid bath. These containers were soaked in this acid bath mixture for a minimum of $4 \mathrm{~h}$. Then, the acid was removed, the aquaria were rinsed with deionized water a minimum of five times, and rinsed again with distilled water.

\subsubsection{Solid-Phase Sample Preparation}

Upon arrival at MSL, the cores and coolers were placed in a cold room at $4^{\circ} \mathrm{C}$ for temporary storage. The reference sediments, from both Disposal Site $F$ and West Beach, were wet-sieved through a $0.5-\mathrm{mm}$-mesh screen. Sediment that passed through the screen was collected in 55-gal, all-glass aquaria. Water used during the sieving was recirculated from the aquaria to the screen with a submersible water pump to provide additional sieving water. Organisms collected on the screen were discarded, and the small amount of remaining debris (composed primarily of shell fragments and coarse material) was added to the sieved sediment. This sieved sediment was allowed to settle at least $6 \mathrm{~h}$, then the overlying water was siphoned off. Next, the sediment was mixed with stainless steel spoons until it was judged that even consistency was obtained.

The cores were composited by extruding them into large stainless steel bowls where they were mixed with stainless steel spoons until the mixture appeared homogeneous. Composite 1 consisted of four cores from Station 6 and 
four from Station 7. Composite 2 was made up of two cores each from Stations 3, 4, and 5. Samples of composites were then taken for chemical analysis. The bowls of composited sediment were covered with sheets of Teflon and placed in the cold room at $4^{\circ} \mathrm{C}$ for temporary storage.

\subsection{CHEMICAL ANALYTICAL PROCEDURES}

\subsubsection{Priority Pollutant Polynuclear Aromatic Hydrocarbons (PAHs), Pesticides, and Polychlorinated Biphenyls (PCBs)}

Sixty-five polynuclear aromatic hydrocarbons (PAHs) were measured by Analytical Resources Incorporated (ARI), Seattle, Washington, using EPAapproved control laboratory protocols (CLP) (Method 625), modified as follows (40 CFR Part 136 1984):

- Analyzed sample weight was increased to a minimum of $50 \mathrm{~g}$ (wet wt) to obtain lower detection limits.

- Gel permeation chromatography (GPC) cleanup using CLP protocol was performed on all samples.

Nineteen priority pollutant pesticides and five aroclor PCBS also were analyzed in each sediment by ARI using approved EPA-CLP protocols (Method 8080), modified as follows (40 CFR Part 136 1984):

- Analyzed sampie weight was increased to a minimum of $50 \mathrm{~g}$ (wet wt) to obtain lower detection limits.

- GPC and alumina cleanup using CLP protocols was performed on all samples.

- Final volumes were reduced to $1 \mathrm{~mL}$, from the normal $10 \mathrm{~mL}$, to provide lower detection limits for the pesticides and PCBS.

\subsubsection{Metals and Metalloids}

Metal and metalloid concentrations were determined through four procedures. Mercury was analyzed with cold-vapor atomic absorption spectrophotometry. Arsenic, lead, zinc, cadmium, chromium, copper, and nickel were analyzed by Zeeman graphite-furnace atomic absorption spectrophotometry.

Sediment was freeze-dried and blended in a mixer-mill. Then, 1.0-g al iquots of this dried homogenate were digested with nitric acid/hydrogen peroxide in glass beakers according to Method 3050 (EPA 1986). 


\subsubsection{Total Organic Carbons}

Total organic carbon in sediment was determined by AMTest, Redmond, Washington, using a nondispersive infrared measurement of carbon dioxide released from the organic carbon during combustion of the sediment. Inorganic carbonates were released from the sediment sample before combustion using hydrochloride. A Dohrmann DC-180 was used to measure carbon dioxide. Duplicate analysis was performed on sediment from Stations 2-1 and $\mathrm{CH}-1$. This method is consistent with Puget Sound Estuary Program (PSEP) (1986) and Standard Method 505 (Standard Methods 1975).

\subsubsection{0il and Grease}

Sediment for the total oil and grease analysis was extracted by weighing approximately $20 \mathrm{~g}$ of sediment into a solvent-rinsed, $250-\mathrm{mL}$ jar. Approximately 40 to $50 \mathrm{~g}$ of anhydrous sodium sulfate was added to the sample and homogenized with the sediment to absorb any water from the sediment. Then, $50 \mathrm{~mL}$ of carbon tetrachloride was added and stirred into this mixture. The sample was then immediately placed on a sample homogenizer for $16 \mathrm{~h}$. After $16 \mathrm{~h}$, the sample was removed from the homogenizer, and the carbon tetrachloride poured into a solvent-rinsed conical vial. An additional $50 \mathrm{~mL}$ of carbon tetrachloride then was added to the sediment, and the sample was rolled an additional $6 \mathrm{~h}$. This second extraction has been shown to ensure $90 \%$ extraction efficiency for various sediment matrices (Word et a7. 1987). These two extracts were combined and measured to the nearest milliliter. Two separate scintillation vials were filled for analysis on a Beckman Acculab $4^{\otimes}$ infrared spectrophotometer (IR).

The sample was scanned from 4000 to $600 \mathrm{~cm}^{-1}$, and the peak height was measured at $2930 \mathrm{~cm}^{-1}$. This wavelength represented the $\mathrm{CH}_{2}$ configurations of hydrocarbons and is the standard used to determine oil and grease. $0 i 1$ and grease may include hydrocarbons, fats, fatty acids, soaps, waxes, oils, and any other carbon-hydrogen material that is extracted by the carbon tetrachloride solvent. The relationship of peak height to the oil concentration was determined by regressing the peak height versus a known concentration of fuel oil (EPA-API Reference 0i1 WP 681). This method is consistent with Method 502 B (Standard Methods 1975). 


\subsubsection{Petroleum Hydrocarbons}

The petroleum hydrocarbon analysis was performed on a portion of the 0i1 and grease extract. Fifty $\mathrm{mL}$ of this extract was mixed with freon to provide $100 \mathrm{~mL}$ of sample in a solvent-rinsed glass jar. This mixture represents a $50 \%$ dilution, which is accounted for in the calculations of the concentrations of the petroleum fraction of the oil and grease measurement. This solution was then mixed on a homogenizer for 5 min with $3 \mathrm{~g}$ of 200-mesh silica ge 1, Grade 922, to remove the polar materials (fatty acids) from the solution. The remaining materials were designated hydrocarbons for this test and were measured using the Beckman Acculab $4^{\otimes}$ infrared spectrophotometer.

As with the oil and grease measurement, the sample was scanned from 4000 to $600 \mathrm{~cm}^{-1}$, and the peak height was measured at $2930 \mathrm{~cm}^{-1}$. This wavelength represented the $\mathrm{CH}_{2}$ configurations of hydrocarbons and was the standard used to determine oil and grease.

To ensure that the silica-gel extraction of fatty acids was effective, this extraction was performed on a sample of American Petroleum Institute (API) crude petroleum and also a sample of cooking-grade corn oil. For the

latter test, $1 \mathrm{~mL}$ of corn oil was dissolved in $100 \mathrm{~mL}$ of freon. This solution was diluted tenfold to obtain an appropriate reading on the infrared spectrophotometer. Thirty $\mu \mathrm{L}$ of the API standard oil was dissolved in $100 \mathrm{~mL}$ of freon. Both of these samples were analyzed on the infrared spectrophotometer, as indicated in the above procedure. The samples were then exposed to the silica-gel extraction procedure and re-analyzed on the infrared spectrophotometer. The procedure was effective, and the corn oil was completely removed from the extract while the petroleum hydrocarbon sample remained essentially unaffected.

\subsubsection{Dissolved Sulfides}

Dissolved sulfide measurements followed the methodology set forth in Green and Schnitker (1974). Zinc acetate preservative solution recommended PSEP and EPA methodologies was added to samples during field collection (PSEP 1986; EPA 1979). A method blank and a spiked recovery (the West Beach sediment treatment) were a7so evaluated. 


\subsubsection{Ammonia Nitrogen}

Ammonia nitrogen was measured according to Standard Methods 417A and 417D [American Public Health Association (APHA) 1985]. Each sample was distilled into a solution of boric acid and titrated with $0.02 \mathrm{~N} \mathrm{H}_{2} \mathrm{SO}_{4}$ with a boric acid indicator containing methyl red and methylene blue. Methylene blue was the end point.

\subsubsection{Grain Size}

Grain size was evaluated by measuring the mass of material collected on seven sieves and also the mass of material that had settled to 20,10 , or $7 \mathrm{~cm}$ in a $1-L$ graduated cylinder at specific time periods. The size of the material was either larger than the specified sieve size opening, or was determined for the pipette-collected material based on Stokes Law (Table 2.5). Mass was determined after the samples had been dried by weighing the material

IABLE 2.5. Size Fractions of Sediment Grain Size Measured by Wet Sieving of Sediment or Through Pipette Techniques

\begin{tabular}{|c|c|c|c|c|c|c|}
\hline \multirow{2}{*}{$\begin{array}{c}\text { Grain Size, } \\
\mathrm{mm}\end{array}$} & \multirow[b]{2}{*}{$\underline{\text { Phi }}$} & \multirow{2}{*}{$\begin{array}{l}\text { Screen } \\
\text { Number } \\
\end{array}$} & \multirow{2}{*}{$\frac{\text { Pipette Depth, }}{\mathrm{cm}}$} & \multicolumn{3}{|c|}{$\begin{array}{c}\text { Time of Pipette } \\
\text { Sampling }\end{array}$} \\
\hline & & & & $\underline{h}$ & $\underline{\min }$ & $\underline{\mathrm{sec}}$ \\
\hline 3.35 & -2.0 & 6 & NA & NA & & \\
\hline 2.0 & -1.0 & 10 & NA & NA & & \\
\hline 1.0 & 0 & 18 & NA & NA & & \\
\hline 0.5 & 1.0 & 35 & NA & NA & & \\
\hline 0.25 & 2.0 & 60 & NA & NA & & \\
\hline 0.125 & 3.0 & 120 & NA & NA & & \\
\hline 0.0625 & 4.0 & 230 & 20 & 0 & 0 & 20 \\
\hline 0.0480 & 4.5 & NA & 10 & 0 & 0 & 55 \\
\hline 0.0312 & 5.0 & NA & 10 & 0 & 1 & 55 \\
\hline 0.0230 & 5.5 & NA & 10 & 0 & 3 & 40 \\
\hline 0.0156 & 6.0 & NA & 10 & 0 & 7 & 41 \\
\hline 0.0078 & 7.0 & $N A$ & 10 & 0 & 31 & 0 \\
\hline 0.0039 & 8.0 & NA & 10 & 2 & 3 & 0 \\
\hline 0.0019 & 9.0 & NA & 7 & 5 & 43 & 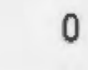 \\
\hline 0.000976 & 10.0 & NA & 7 & 22 & 53 & 0 \\
\hline 0.0004883 & 11.0 & NA & 5 & 65 & 25 & 0 \\
\hline
\end{tabular}


to the nearest $0.1 \mu \mathrm{g}$ on an electronic balance. Salt content was then accounted for. This method is consistent with PSEP methodology (PSEP 1986).

\subsection{TOXICOLOGICAL TESTING PROCEDURES}

As part of the toxicological testing program, the laboratory at MSL was specifically set up to provide the facilities required for flow-through and static solid-phase bioassays. Four constant-temperature water baths were set up, as shown in Figure 2.3. These water baths contained the test equipment (Figure 2.4) for the following bioassays:

- flow-through, solid-phase clam/polychaete (‥ nasuta/‥ caecoides)

- flow-through, solid-phase clam bioaccumulation (… nasuta)

- flow-through, solid-phase amphipods (R. abronius/的. japonica)

- static, solid-phase amphipods (‥ abronius/ $\underline{G}$.japonica).

The facilities provided air, temperature control, lighting, and flowthrough water supply as needed, as well as warning signals for potential equipment malfunctions.

\subsubsection{Solid-Phase Tests}

\section{Test Dbjectives}

The solid phase of a dredged material was represented in this test by a layer of sediment collected from proposed dredging sites. During the solidphase tests, a $1.5-\mathrm{cm}$-thick layer of test sediment was placed on top of a $3-\mathrm{cm}$-thick layer of reference sediment from Disposal Site F. This layer was intended to provide an approximation of exposure conditions that might be experienced by benthic organisms living in sediment near the boundary of a disposal site. The tests evaluated effects caused by both the physical presence of dredged sediment and the toxicity of contaminants associated with them. These tests were not intended to evaluate the impact of dredged materials that might occur directly beneath a disposal vessel. 
C1 DSC2 DS C2 C1 DS DS C2 C1

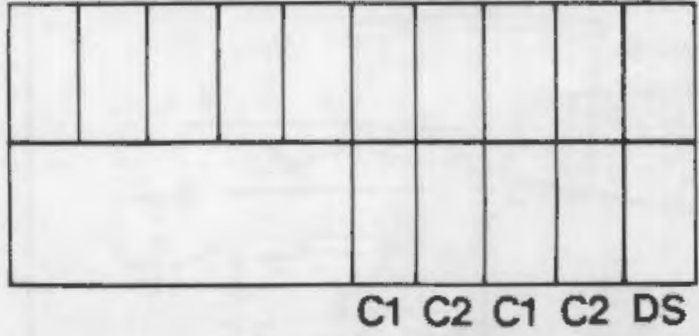

C2 C1 C2 DSC1 DSC2 DSC1 DS

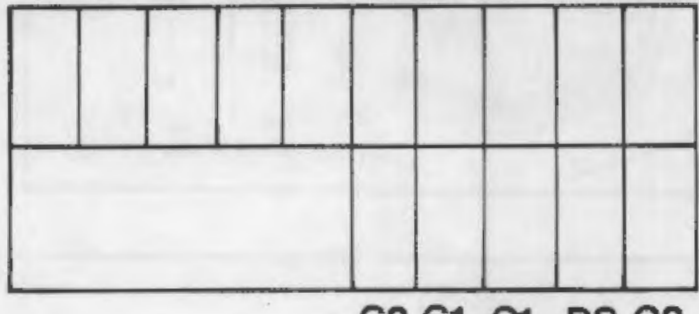

C2 C1 C1 DS C2

WB DS WB DS C1 C2 WB C2 DS WB

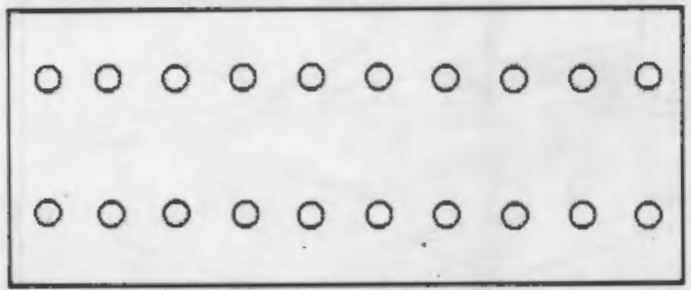

WB C1 C2 C1 C2 C1 DS C2 C1 DS

C1 C2 WB DS WB DS C2 DS C2 C1

0000000000

0000000000

DS C1 WB C1 DS C1 C2 WB C2 WB
Macoma/Nephtys Bioassay

10-Day

Macoma Bioaccumulation

20-Day

Rhepoxynius/Grandidierella

Static Bioassay

10-Day

Rhepoxynius/Grandidierella

Flow-Through Bioassay

10-Day

FIGURE 2.3. Aquarium Arrangement for Bioassays

The solid-phase tests were conducted with four marine species, including a detrital-feeding $\mathrm{clam}$, a deposit-feeding polychaete, and two burrowing crustaceans. The amphipods chosen included a tube-building organism that prefers fine sediments and a non-tube-builder that lives in coarser material. This design allowed us to evaluate a range of sediment types using organisms with different life habits. 
Macoma/Nephtys Bioassay

Bioaccumulation

\section{Amphipod}

Static

Bioassay

\section{Amphipod}

Flow-Through

Bioassay
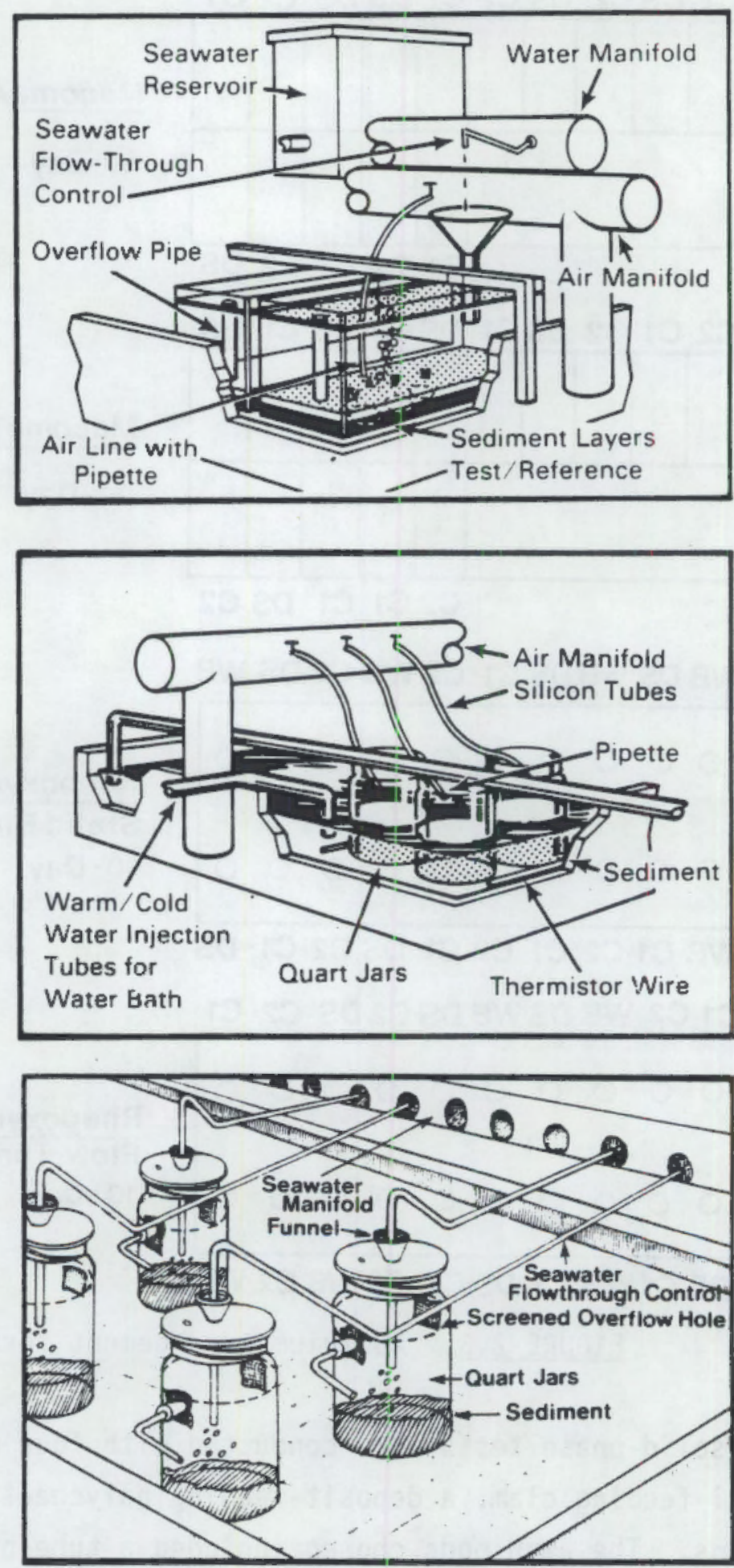

FIGURE 2.4. Bioassay Test Equipment 


\section{Overall Experimental Design}

This experimental design was devised to fulfill testing requirements of the Federal Register (1977) and the Implementation Manual (EPA/USACE 1977). Appropriate literature and/or protocols are also be found in EPA (1976, 1978), APHA (1985), and American Society for Testing and Materials (ASTM) $(1980 \mathrm{a}, \mathrm{b})$.

The experimental design for the solid-phase tests is summarized in Section 2.1 and Table 2.2. Four sediment treatments from Tongue Point, Disposal Site $F$, and west Beach were tested. Protocols for preparing these sediment samples for the solid-phase tests are specified in Section 2.3.3. Three solid-phase bioassays were conducted, two flow-through, tests and a static test. Each experiment lasted 10 days. One flow-through test using the bent nose clam (․․ nasuta) and the polychaete (N. caecojdes) was conducted in individual $38-L$ aquaria connected to a temperature-regulated, flow-through seawater system. Twenty-five $\underline{M}$. nasuta and $20 \mathrm{~N}$. caecojdes occupied each test aquarium. The other flow-through test and the static test evaluated the response of two amphipods, $\underline{G}$. japonica and $\underline{R}$. abronius. Twenty $\underline{R}$. abronius and $20 \mathrm{G}$. japonica shared each test container ( $1-\mathrm{L}$ jars) during this study. Each flow-through jar had an inlet for seawater at the top and an outlet on the side to allow a continuous flow of water through the jar. The static jars contained the same water throughout the testing period. Temperature was regulated by placing the containers, both static and flow-through, in a temperature-controlled seawater bath. In addition to the bioassays, a 20 -day bjoaccumulation test was also conducted using $\underline{M}$. nasuta in $38-\mathrm{L}$, flow-through aquaria.

Five replicate containers, randomly placed on water tables, were used for each sediment treatment in all tests. The test containers were first layered with clean reference sediment from Disposal Site $F$ to a depth of $3 \mathrm{~cm}$. The bent nose clam (․․ nasuta) was randomly distributed among the $38-\mathrm{L}$ aquaria and allowed to burrow into the reference sediment. Any clams not burrowing were replaced. Forty-eight hours after these animals were added to the containers, the test or reference sediment was deposited on the Disposal Site $F$ sediment to a depth of $1.5 \mathrm{~cm}$. Only the amphipod tests received West 
Beach sediments. The polychaete $\underline{N}$. caecoides and the amphipods $\underline{G}$. japonica and $\underline{R}$. abronius were added to the test containers after this second deposit was added.

During the tests, water quality parameters were monitored daily. Temperature was held at $15 \pm 1^{\circ} \mathrm{C}$; salinity was maintained at Sequim Bay ambient levels for September (approximately $32 \pm 1 \%$ ). Dissolved oxygen was monitored to ensure that at least $4.0 \mathrm{mg} / \mathrm{L}$ was present during tests. The static test required aeration; the flow-through test did not. The $\mathrm{pH}$ was monitored, but not corrected, as it did not change more than 0.4 during the tests.

\section{Bioassay Protocols}

Collection and Handling: Polychaete (N. caecoides) and Bent Nose Clam (M. nasuta). Polychaetes (N. caecojdes) were collected from a Tomales Bay, California, mudflat on August 26, 19B8, using a shovel and 1.0-mm sieve. Approximately 500 adults were shipped to MSL. They arrived in a large waterproof box containing native sediment (fine sand) and water. The animals were kept in the shipping container approximately $6 \mathrm{~h}$ and allowed to gradually acclimatize to MSL conditions. After the 6-h holding period, the sediment and polychaetes were transferred directly into a large holding container with a temperature maintained at $15^{\circ} \mathrm{C}$ through a regulated flowthrough seawater system. The polychaetes were kept in this system until used. Water quality was checked daily.

The bent nose clams (ㅆ․ nasuta) were collected from three sites on the 0lympic Peninsula, Washington, near the MSL facility. About $1000 \mathrm{clams}$ were collected. The clams were transported immediately to MSL where the temperature was gradually increased from their natural ambient temperature of $12^{\circ}$ to $15^{\circ} \mathrm{C}$ over 3 days. Clams (ㅆ. nasuta) were stored in large holding tubs with MSL beach sediment and a temperature-regulated, flow-through seawater system. Water quality was checked daily.

Test Preparation and Conduct: Polychaetes, flams. For the flow-through test using polychaetes (N. caecoides) and/or bent nose clams (ㅆ. nasuta), test aquaria were placed randomly on water tables and filled to a depth of $3 \mathrm{~cm}$ with sediment from the Columbia River reference station. This sediment 
had been wet-sieved through a 1.0-mm-diameter Nytex screen the previous day and allowed to settle overnight. The flow-through system was initiated, and aquaria were allowed to fill to a total volume of approximately $36 \mathrm{~L}$. During this time, the flow-through system was adjusted and calibrated to deliver $125-\mathrm{mL} / \mathrm{min}$ seawater flow $(4 \mathrm{~L} / \mathrm{h})$ to each aquarium.

After $4 \mathrm{~h}, 75 \%$ of the water was removed, $25 \mathrm{clams}$ (ㅆ. nasuta) and 20 polychaetes ( $\underline{N}$. caecoides) were added to each bioassay aquarium and $25 \mathrm{clams}$ only to the bioaccumulation aquaria, and a $48-\mathrm{h}$ equilibration period initiated. During this period, water quality checks were made, and test organisms were observed for abnormal behavior or mortality. Dead organisms were removed and replaced. After $48 \mathrm{~h}, 75 \%$ of the water was removed from each aquarium, and a layer of test sediment $1.5-\mathrm{cm}$ thick was placed on the Point Reyes sediment. The aquaria were allowed to fill again via the flowthrough system, and the 10-day test period began. Daily observations included checks on animal behavior and water quality parameters of salinity, temperature, D.0., and pH. Test organisms were not fed during the 10-day bioassay or 20-day bioaccumulation.

At the end of the bioassay and bioaccumulation tests, contents of each aquarium were carefully passed through 1.0-mm Nytex ${ }^{\circledR i e v e s, ~ a n d ~ a n i m a l s ~}$ captured were counted and classified as alive or dead. The $\underline{M}$. nasuta were then transferred to clean $38-\mathrm{L}$ aquaria and the $\underline{\mathrm{N}}$. caecoides to $4-\mathrm{L}$ Pyrex ${ }^{\circledR}$ baking dishes. The aquaria and baking dishes were transferred to a water table containing a $15^{\circ} \mathrm{C}$ water bath and aerated. The organisms were allowed to depurate for a period of $48 \mathrm{~h}$. Fecal material was removed from each tank twice daily. At the end of the depuration period, the clams from selected sediment treatments were prepared for bioaccumulation analysis, and the polychaetes and remaining clams were frozen and archived.

Collection and Handling: Amphipod (G. japonica and R. abronius). R. abronius were collected from West Beach, Whidbey Island, Washington, using an infaunal dredge constructed by MSL personne1. The animals were transported to MSL within $4 \mathrm{~h}$ of collection in large tubs containing native sediment (sand) and seawater. At MSL, they were transferred to holding vessels integrated into MSL's flow-through seawater system. The seawater was 
gradually increased from West Beach's ambient temperature $\left(9^{\circ} \mathrm{C}\right)$ to $15^{\circ} \mathrm{C}$ over a period of $24 \mathrm{~h}$. Water quality was checked daily in holding vessels. Animals were not fed before or during the test.

G. japonica were collected in Southwest San Pablo Bay, California, in 14 to $18 \mathrm{ft}$ of water using a bottom grab and a towed 215- $\mu \mathrm{m}$ weighted plankton net. Material collected was sieved through a $0.5 \mathrm{~mm}-\mathrm{mesh}$ screen to collect the amphipods. The animals were shipped to MSL on August 26, 1988, in containers with native sediment. The amphipods and native sediment were held in a flow-through fiberglass tank after the water was gradually exchanged for filtered Sequim Bay seawater, and parameters were slowly adjusted. The temperature was held at $15.0 \pm 1{ }^{\circ} \mathrm{C}$ until the amphipods were used.

Test Preparation and Conduct: Amphipods. For the amphipod (G. japonica and $\underline{R}$. abronius) static test, 100 1-L test containers were randomly arranged on a water table containing $15^{\circ} \mathrm{C}$ freshwater. Each static container was layered with $3 \mathrm{~cm}(150 \mathrm{~mL})$ of $0.5-\mathrm{mm}$ sieved sediment from the Disposal Site $\mathrm{F}$ reference station, then slowly filled to the $800-\mathrm{mL}$ mark with filtered Sequim Bay seawater. The containers were allowed to equilibrate for $48 \mathrm{~h}$ at $15^{\circ} \mathrm{C}$. The flow-through jars were similarly layered with sieved sediment, and $15^{\circ} \mathrm{C}$ Sequim Bay water was added at a rate of $40 \mathrm{~mL} / \mathrm{min}$. These jars were also al lowed $48 \mathrm{~h}$ of equilibration. At the end of this period, the test sediment was carefully added to each container to a depth of $1.5 \mathrm{~cm}(75 \mathrm{~mL})$, aeration was supplied to the static containers, and all containers were allowed to settle overnight. The following day, $75 \%$ of the overlying water in the static jars was siphoned from each container, and slowiy replaced with fittered Sequim Bay seawater to a volume of $800 \mathrm{~mL}$. The amphipods (R. abronius and $\underline{G}$. japonica) were carefully removed from the holding tanks, counted, and allocated to each exposure jar, again in random order. A total of 20 R. abronius and $20 \underline{G}$. japonica were placed in each jar. Daily animal observations included the number of $\underline{R}$. abronius and $\underline{G}$. japonica present on the sediment and water surface, and the number of dead individuals. For this test, death was defined as a lack of pleopod movement after stimulation with a glass probe. Dead animals were enumerated and removed without replacement. 
Test organisms were not fed during the bioassay. Water quality checks were performed daily on all containers, and included measurements of temperature, salinity, $\mathrm{pH}$, and D.0.

At the end of the 10-day bioassay, the contents of each exposure jar were carefully washed through a $0.5-\mathrm{mm}$-diameter sieve, and the animals were transferred to clean, labeled glass petri dishes containing $15^{\circ} \mathrm{C}$ seawater for observation and enumeration. Counts were performed on each dish to determine the number of $\underline{R}$. abronius and $\underline{G}$. japonica alive and dead at the end of the test, as well as total number recovered.

\subsubsection{Bioaccumulation Measurements}

At the end of the 20-day bioaccumulation test, living $\underline{M}$. nasuta from each aquarium were placed in containers of clean seawater and allowed to depurate for 2 days. At the end of this period, individuals within a replicate were randomily allocated for selected metal analysis. Each individual was removed from its shell by dissection with titanium instruments, and placed in labeled containers until analysis. Samples were placed in clean Tefion jars and analyzed at MSL.

Tissue samples for metals analysis were first freeze-dried to remove moisture, then pulverized using a ball-mill apparatus. A 0.5-g sample of dried tissue material was weighed into a Teflon bomb, and $3 \mathrm{~mL}$ of $4: 1$ $\mathrm{HNO}_{3} / \mathrm{HCLO}_{4}$ was added. The bombs were placed on a warm hot plate for 2 to $3 \mathrm{~h}$, allowing the nitric acid fumes to vent. The bombs were then placed in an oven at $130^{\circ} \mathrm{C}$ for $4 \mathrm{~h}$. After cooling, $20 \mathrm{~mL}$ of deionized-distilled water was added to each bomb, and the solution weights were recorded. The solution was then transferred to an acid-rinsed $30-\mathrm{mL}$ polybottle until analysis. Lead, cadmium, copper, zinc, and mercury were measured by atomic absorption spectrophotometry, described in Secfion 2.4.2.

\subsection{QUALITY ASSURANCE/QUALITY CONTROL PROCEOURES}

Quality assurance (QA) and quality control (QC) procedures followed for these studies were consistent with the Implementation Manual (EPA/USACE 1977) and EPA Region 10 protocois (PSEP 1986). The procedures followed were presented by Pacific Northwest Laboratory's (PNL) Quality Engineering Division 
as a QA Plan, Number EES-20, Revision 1. The PNL. Laboratory Record Book (LRB) was used for all phases of this project for recording day-to-day activities during the research. All entries in the LRBs were signed, dated, and reviewed by both the project manager, Jack Q. Word, and the quality assurance engineer, Rob Cuello. The following discussion summarizes QA/QC procedures followed for the three main portions of this study: sediment sampling, biological testing, and chemical testing. $A 1\} Q A / Q C$ evaluations are contained in Appendix E.

\subsubsection{Sediment Sampling, Storage, and Tracking}

A11 sediment collected for these studies was stored in glass or cellulose acetate butyrate (CAB) containers before use. Sediment was stored at $4^{\circ} \mathrm{C}$, kept in the dark until used, and never frozen. Tracking forms were developed and unique labels attached to each sample. A summary of field collection information is presented in Table 2.3. These procedures were consistent with Appendices $B$ and $D$ of the Implementation Manual (EPA/USACE 1977 ) and follow accepted EPA Region 10 protocols (PSEP 19B6).

\subsubsection{Biological Testing}

\section{Care and Handiing of Test Organisms}

Test organisms were handled carefully during collection and transfer to test containers. Organisms shipped to MSL were gradually equilibrated to ambient surroundings and kept in their native sediment whenever possible. Organisms were transferred to test containers by either pipetting, netting, or quantitative transfer. Animals were not touched by hand or exposed to air during transfer. A short summary of collection and handiing of each test species is included above, in Section 2.5 of this report.

\section{Species Selection and Identification}

Selection of species was consistent with the Implementation Manual (Appendix F.1) and included the use of burrowing invertebrates and depositfeeding organisms. Representatives of all test organisms were taxonomically identified by qualified experts at MSL before use in bioassays. 


\section{Water Quality Checks}

During all bioassay tests, water quality checks were performed to ensure that acceptable experimental conditions were maintained. These conditions included a stable temperature $\left( \pm 2.0^{\circ} \mathrm{C}\right)$, a lower dissolved-oxygen limit $(4.0 \mathrm{mg} / \mathrm{L})$, and $14 \mathrm{~h}$ of light per day. Salinity was allowed to vary $\pm 2.0 \%$, and $\mathrm{pH}$ was allowed to vary \pm 0.4 units within each container during the bioassay period. These limits and values are consistent with those outlined in the Implementation Manual (EPA/USACE 1977). Water quality instruments were calibrated according to the manufacturers specifications, or accepted PNL protocols. Information concerning equipment and calibration procedures are included in Appendix $D$.

\subsubsection{Chemical Testing}

Chemical testing protocols required by $Q A / Q C$ and listed in PNL-MA-70 include the following:

- analysis of a reagent blank

- $20 \%$ of the samples spiked (when possible) with an appropriate standard to address accuracy

- printouts from $A A$ and $G C$ analysis kept on file.

All these protocols were followed during this study and are summarized in the following paragraphs.

\section{Measurements of Accuracy}

Measurements of accuracy are derived by using standard reference materials (SRM). For metals, SRMs included PACS-1, MESS, and 1646. The PAH analytical accuracy was checked against SRM SQ-1, and pesticides and PCBs were checked against SRM SQI and also samples of Endosulfan II and aroclor1254. Standard reference materials were not avajlable for measurements of dissolved sulfide, total organic carbon, ammonia, oil and grease, petroleum hydrocarbons, or grain size.

\section{Equipment Printouts and Data}

A1) MSL analytical equipment printouts are filed for future reference. Procedures and related data were written into the LRB. Offsite analysis (ARI/AmTest) original printouts are stored with the analytical equipment, but 
are available for inspection. Samples were tracked and tied to a particular device at all testing laboratories through chain-of-custody procedures.

\subsection{STATISTICAL DESIGN, DATA ANALYSIS, AND INTERPRETATION}

The purpose of the statistical analyses was to determine the statistical significance and magnitude of the toxicity of each sediment treatment from Tongue Point and compare them with reference sediment from Disposal site $F$. For the amphipod bioassays an additional sediment from West Beach, Whidbey Isiand, was used as a reference. The toxicity was ranked based on the survival detected after a 10- or 20-day exposure to sediment. In addition, the possible causes of the toxicity were examined by jointly analyzing the chemical composition of each station and the resultant toxicity ranking.

\subsubsection{Randomization}

Solid-phase bioassays were conducted as completely random designs. Organisms were randomly allocated to treatments, and treatments were randomly allocated to positions within the water tables. Separate random number tables were generated for each of the bioassays for this purpose, using the discrete uniform random number generator available in STATGRAPHICS.

\subsubsection{Solid-Phase Bioassays}

For the solid-phase bioassays, sediment was compared by analysis of variance (ANOVA) tests on the arc sine square root of the proportion surviving to the tenth day. The transformation of arc sine square root was used to stabilize the within-class variances to meet the assumptions of the ANOVA. If the survival for at least one of the samples was significantly different, the samples were compared using the conservative Tukey's Honestly Significant Difference (HSD) test for all possible comparisons (Steel and Torrie 1980), which uses an experiment-wide error rate. Thus, the type I error for the combined conclusions could be established at $\alpha=0.05$. The ANOVAs were performed on survival data for both flow-through and static bioassays (as recommended by the Implementation Manual). 


\subsection{RESULTS AND DISCUSSION}

\subsection{SOLID-PHASE TESTS}

\section{1 .1 Polychaetes ( $N$. caecoides) and Clams ( $M$. nasuta)}

Table 3.1 summarizes survival data of the solid-phase tests on polychaetes (․․ caecoides) and clams (․․ nasuta). Because the polychaetes and clams were tested together in the bioassay, the results are reported together in this section. Most of the polychaetes ( $\underline{\mathbb{N}}$. caecoides) and all of the clams (ㅆ. nasuta) survived the 10-day solid-phase flow-through series.

IABLE 3.1. Number of Test Animals A] ive at the End of the Four Bioassays. Each Test Began With 25 Macoma and Individuals of the 0ther Species

\begin{tabular}{|c|c|c|c|c|c|c|c|c|}
\hline \multirow[b]{2}{*}{ Treatment } & \multirow[b]{2}{*}{ Rep } & \multicolumn{2}{|c|}{ Grandidierella } & \multicolumn{2}{|c|}{ Rhepoxynius } & \multirow{2}{*}{$\frac{\text { Macoma }}{10-d}$} & \multirow{2}{*}{$\frac{\text { Nephtys }}{10-d}$} & \multirow{2}{*}{$\frac{\text { Macoma }}{20-d}$} \\
\hline & & $F T^{(a)}$ & $S^{(a)}$ & $\mathrm{FT}$ & $\mathrm{S}$ & & & \\
\hline Cl & $\begin{array}{l}1 \\
2 \\
3 \\
4 \\
5\end{array}$ & $\begin{array}{l}18 \\
16 \\
20 \\
20 \\
20\end{array}$ & $\begin{array}{l}12 \\
\ldots \text { (b) } \\
20 \\
19 \\
16\end{array}$ & $\begin{array}{l}20 \\
19 \\
18 \\
14 \\
19\end{array}$ & $\begin{array}{l}12 \\
--(b) \\
19 \\
18 \\
12\end{array}$ & $\begin{array}{l}25 \\
25 \\
25 \\
25 \\
25\end{array}$ & $\begin{array}{l}16 \\
20 \\
20 \\
20 \\
20\end{array}$ & $\begin{array}{l}25 \\
25 \\
24 \\
24 \\
24\end{array}$ \\
\hline
\end{tabular}

C2

$\begin{array}{lllll}1 & 20 & 19 & 18 & 18 \\ 2 & 18 & 18 & 17 & 18 \\ 3 & 20 & 12 & 17 & 17 \\ 4 & 19 & 17 & 18 & 17 \\ 5 & 17 & 18 & 17 & 14 \\ & & & & \\ 1 & 20 & 18 & 19 & 20 \\ 2 & 18 & 20 & 20 & 20 \\ 3 & 19 & 20 & 17 & 20 \\ 4 & 19 & 18 & 19 & 20 \\ 5 & 20 & 20 & 18 & 19 \\ & & & & \\ 1 & 20 & 18 & 20 & 20 \\ 2 & 20 & 20 & 18 & 20 \\ 3 & 20 & 19 & 19 & 19 \\ 4 & 19 & 20 & 20 & 20 \\ 5 & 20 & 18 & 19 & 21\end{array}$

(a) $\mathrm{FT}=$ flow-through, $S=$ static.

(b) Jar Cl, Rep 2 of the amphipod static bioassay was dropped during monitoring. 
Water-quality parameters remained within acceptable ranges, as summarized in Section 2.6.2 and described in the Implementation Manual (EPA/USACE 1977). The flow-through system regulated temperature consistently within the $\pm 1^{\circ} \mathrm{C}$ target, with a minimum water temperature of $15.5^{\circ} \mathrm{C}$ and a maximum of $16.5^{\circ} \mathrm{C}$. Dissolved oxygen ranged from 6.6 to $8.2 \mathrm{mg} / \mathrm{L}$; salinity ranged from 32.0 to $33.0 \%$, which is normal ambient salinity for Sequim Bay. The pH ranged from 7.06 to 8.11 and varied less than 0.4 units within each replicate container.

None of the clams ( $M$. nasuta) died during the 10-day bioassay. The proportions of polychaetes ( $\underline{\mathbb{N}}$. caecoides) surviving the 10-day exposure to three sediment treatments are summarized for each sediment treatment in Table 3.2. The mean proportion survival ranged from 0.95 to 0.97 for sediment treatments DS (Disposal Site F) and C2 (Composite 2), respectively. One-way analysis of variance (ANOVA) on the arcsine square root of the proportion surviving did not detect significant $(\alpha=0.05)$ differences between the three sediment treatments (Table 3.3). The proportion of clams (M. nasuta) surviving the 20-day bioaccumulation exposure to three treatments are summarized for each sediment treatment in Table 3.4. The mean proportion surviving ranged from 0.968 in treatment DS (Disposal Site F) to 1.00 in C2 (Composite 2). One-way analysis of variance (ANOVA) on the arcsine square root of the proportion surviving again did not detect significant $(\alpha=0.05)$ differences among the three sediment treatments (Table 3.5).

TABLE 3.2. Proportion of Polychaetes (N. caecoides) Surviving After 10-Day Exposure to Three Sediment Treatments and Comparison of the Means

\begin{tabular}{|c|c|c|c|}
\hline $\begin{array}{l}\text { Sediment } \\
\text { Treatment }\end{array}$ & $\begin{array}{l}\text { Mean Proportion } \\
\text { Surviving } \\
\end{array}$ & $\begin{array}{l}\text { Standard } \\
\text { Deviation }\end{array}$ & $\begin{array}{l}\text { Statistical } \\
\text { Group (a) }\end{array}$ \\
\hline DS & 0.95 & 0.050 & $A$ \\
\hline $\mathrm{Cl}$ & 0.96 & 0.089 & $A$ \\
\hline $\mathrm{C} 2$ & 0.97 & 0.027 & A \\
\hline
\end{tabular}

(a) Treatments within the same statistical group are not significantly $(\alpha=0.05)$ different (Tukey's HSD multiple comparison). 
IABLE 3.3. Balanced One-Way ANOVA for Three Sediment Treatments Using the Arc Sine (Expressed in Radians) Square Root of the Proportion of $\underline{\mathrm{N}}$. caecoides Surviving a 10-Day, Solid-Phase Exposure

\begin{tabular}{|c|c|c|c|c|c|}
\hline $\begin{array}{l}\text { Source of } \\
\text { Variation }\end{array}$ & $\begin{array}{l}\text { Sum of } \\
\text { Squares }\end{array}$ & D.F. & $\begin{array}{c}\text { Mean } \\
\text { Square }\end{array}$ & F-Ratio & $\begin{array}{c}\begin{array}{c}\text { Significance } \\
\text { Level }\end{array} \\
-\end{array}$ \\
\hline Between groups & 0.016 & 2 & 0.008 & 0.290 & 0.753 \\
\hline Within groups & 0.340 & 12 & 0.028 & & \\
\hline Total & 0.356 & 14 & & & \\
\hline
\end{tabular}

TABLE 3.4. Proportion of Clams (M. nasuta) Surviving After 20-Day Exposure to Three Sediment Treatments and Comparison of the Means

\begin{tabular}{|c|c|c|c|}
\hline $\begin{array}{l}\text { Sediment } \\
\text { Treatment }\end{array}$ & $\begin{array}{c}\text { Mean } \\
\text { Proportion } \\
\text { Surviving } \\
\end{array}$ & $\begin{array}{l}\text { Standard } \\
\text { Deviation }\end{array}$ & $\begin{array}{l}\text { Statistjcal } \\
\text { Group } \\
\end{array}$ \\
\hline DS & 0.97 & 0.044 & A \\
\hline $\mathrm{Cl}$ & 0.98 & 0.022 & A \\
\hline $\mathrm{C} 2$ & 1.00 & 0.000 & A \\
\hline
\end{tabular}

(a) Treatments within the same statistical group are not significantly $(\alpha U=0.05)$ different (Tukey's HSD multiple comparison.

TABLE 3.5. Balanced One-Way ANOVA for Three Sediment Treatments Using the Arc Sine (Expressed in Radians) Square Root of the Proportion of $\underline{M}$. nasuta Surviving a 20-Day, Solid-Phase Exposure

\begin{tabular}{|c|c|c|c|c|c|}
\hline $\begin{array}{l}\text { Source of } \\
\text { Variation }\end{array}$ & $\begin{array}{l}\text { Sum of } \\
\text { Squares }\end{array}$ & D.F. & $\begin{array}{l}\text { Mean } \\
\text { Square }\end{array}$ & F-Ratio & $\begin{array}{c}\text { Significance } \\
\text { Level }\end{array}$ \\
\hline Between groups & 0.046 & 2 & 0.023 & 1.886 & 0.1939 \\
\hline Within groups & 0.147 & 12 & 0.012 & & \\
\hline Tota 1 & 0.193 & 14 & & & \\
\hline
\end{tabular}

\subsubsection{Amphipods (R. abronius and G. japonica)}

Water-quality parameters for this experiment remained within the acceptable ranges stated in the Implementation Manual (EPA/USACE 1977). Temperature ranged from $14.5^{\circ}$ to $15.0^{\circ} \mathrm{C}$ (a range of $0.5^{\circ} \mathrm{C}$ ). Salinity ranged from 32 to $34 \%$ in both tests, and varied less than $1.0 \%$ within each 
jar. Dissolved oxygen levels remained above the minimum level of $4.0 \mathrm{mg} / \mathrm{L}$, with a low of $7.3 \mathrm{mg} / \mathrm{L}$ and a high of $8.2 \mathrm{mg} / \mathrm{L}$ in the static experiment and a range of 6.2 to $8.2 \mathrm{mg} / \mathrm{L}$ in the flow-through experiment. The $\mathrm{pH}$ in the static containers varied 0.68 units, ranging from 7.64 to 8.32 , but varied less than 0.5 units within each container over the 10 -day test. The $\mathrm{pH}$ varied less in the flow-through jars.

\section{Comparison of Percent Survival: Amphipod (R.mabronius)}

The mean proportion survival of the amphipod $\underline{R}$. abronius in the flowthrough test, as shown in Table 3.6, was lowest in treatment $C 2(0.87)$ and highest in treatment WB (0.96). The one-way ANOVA on the arcsine square root transformed data showed that the mean proportion survival was not significantly $(\alpha=0.05)$ different in the four sediment treatments (Table 3.7 ).

Tukey's HSD method for multiple comparison produced two statistical groups for $\underline{\mathrm{R}}$. abronius in the static treatments, separating the higher survival percentage observed for the Disposal Site F (DS) and West Beach (WB) sediments from the lower observed survival percentage obtained from sediment treatments $\mathrm{Cl}$ and $\mathrm{C} 2$ (Table 3.8). One jar from treatment $\mathrm{C} 1$ was dropped during the exposure period. As a result, $\mathrm{Cl}$ contained only four replicates. One-way ANOVA among all static treatments using the angular transformed data was significant $(\alpha=0.0002)$ (Table 3.9$)$.

TABLE 3.6. Proportion of Amphipods (R. abronius) Surviving After 10-Day Flow-Through Exposure to Four Sediment Treatments and Comparison of the Means

\begin{tabular}{|c|c|c|c|}
\hline $\begin{array}{l}\text { Sediment } \\
\text { Treatment } \\
\end{array}$ & $\begin{array}{l}\text { Mean } \\
\text { Proportion } \\
\text { Surviving } \\
\end{array}$ & $\begin{array}{l}\text { Standard } \\
\text { Deviation }\end{array}$ & $\begin{array}{c}\text { Statistjcal } \\
\text { Group }\end{array}$ \\
\hline DS & 0.93 & 0.057 & A \\
\hline WB & 0.96 & 0.042 & A \\
\hline $\mathrm{Cl}$ & 0.90 & 0.117 & A \\
\hline$C 2$ & 0.87 & 0.027 & A \\
\hline
\end{tabular}

(a) Treatments within the same statistical group are not significantly $(\alpha=0.05)$ different (Tukey's HSD multiple comparison). 
TABLE 3.7. Balanced One-Way ANOVA for Four Sediment Treatments Using the Arc Sine (Expressed in Radians) Square Root of the Proportion of $\underline{R}$. abronius Surviving a 10-Day, Solid-Phase, Flow-Through Exposure

\begin{tabular}{|c|c|c|c|c|c|}
\hline $\begin{array}{l}\text { Source of } \\
\text { Variation }\end{array}$ & $\begin{array}{l}\text { Sum of } \\
\text { Squares }\end{array}$ & D.F. & $\begin{array}{c}\text { Mean } \\
\text { Square }\end{array}$ & $\underline{\text { F-Ratio }}$ & $\begin{array}{c}\text { Significance } \\
\text { Leve } 7\end{array}$ \\
\hline Between groups & 0.117 & 3 & 0.039 & 1.743 & 0.1985 \\
\hline Within groups & 0.357 & 16 & 0.022 & & \\
\hline Total & 0.474 & 19 & & & \\
\hline
\end{tabular}

TABLE 3.8. Proportion of Amphipods (R. abronius) Surviving After 10-Day Static Exposure to Four Sediment Treatments and Comparison of the Means

\begin{tabular}{|c|c|c|c|}
\hline $\begin{array}{l}\text { Sediment } \\
\text { Ireatment }\end{array}$ & $\begin{array}{l}\text { Mean } \\
\text { Proportion } \\
\text { Surviving }\end{array}$ & $\begin{array}{l}\text { Standard } \\
\text { Deviation }\end{array}$ & $\begin{array}{l}\text { Statistjcal } \\
\text { Group } \\
\end{array}$ \\
\hline DS & 0.99 & 0.022 & A \\
\hline WB & 0.99 & 0.022 & A \\
\hline $\mathrm{Cl}$ & 0.76 & 0.189 & B \\
\hline$C 2$ & 0.84 & 0.082 & B \\
\hline
\end{tabular}

(a) Treatments within the same statistical group are not significantly $(\alpha=0.05)$ different (Tukey's HSD multiple comparison).

The 95\% confidence intervals about the true angular transformed means further support the results obtained by the multiple comparison procedure (Figure 3.1). The percentage of $\underline{R}$. abronius surviving the 10-day static bioassay for each sediment treatment is presented in Table 3.8.

The relatively high survival percentage in the Disposal Site $F$ (DS) and West Beach (WB) reference sediments (5\% or less mortality) in both the flowthrough and static tests indicate that the bioassays were successfu1. The weighing factor in the static test that accounts for the significant difference in survival between reference and Tongue Point sediments is the low standard deviation (SD) in the proportion of $\underline{R}$. abronius surviving the reference treatments, whereas the proportion surviving treatment $\mathrm{C} 1$ had a relatively high SD. 


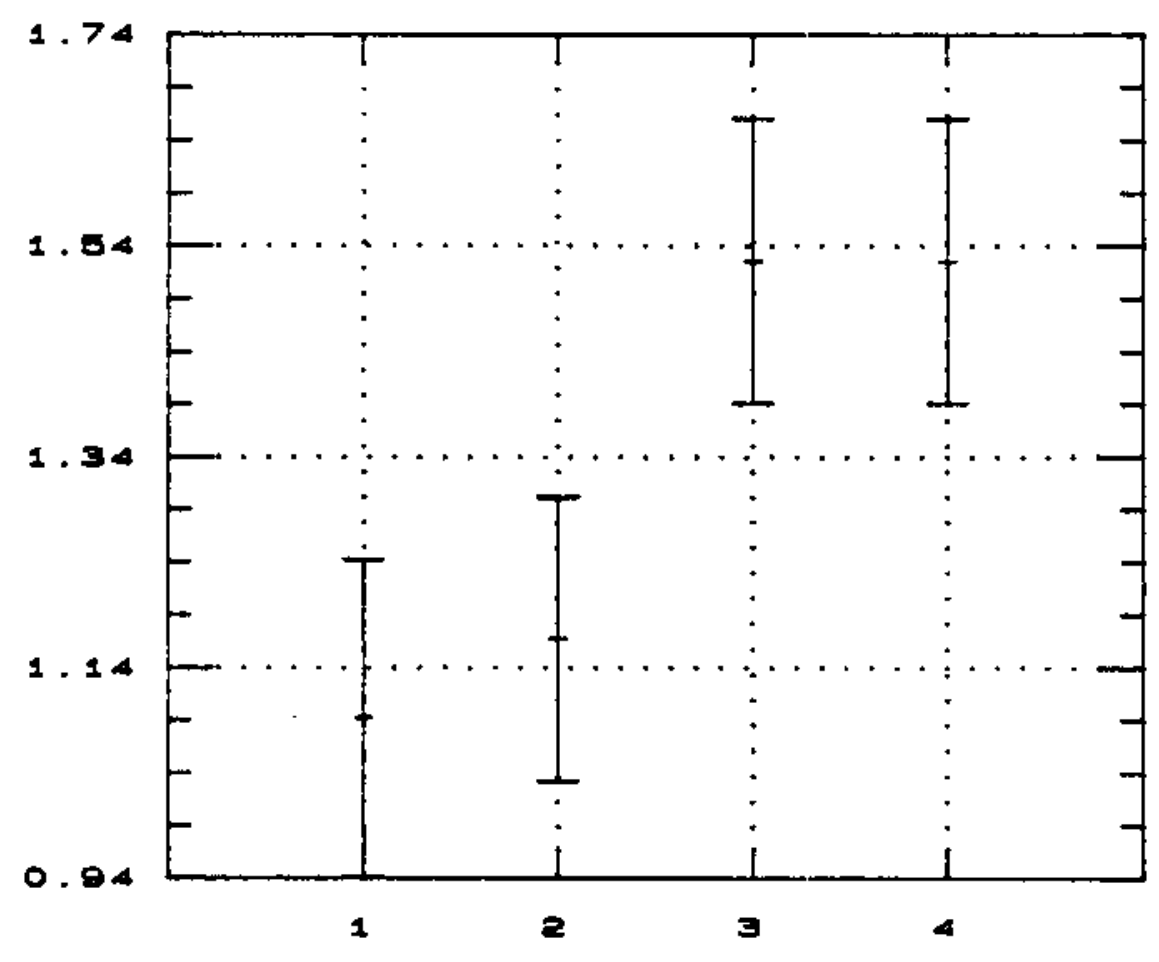

FIGURE 3.1. 95\% Confidence Intervals About the True Angular Transformed Means of $\underline{R}$. abronius Surviving the 10-Day Static Exposure

IABLE 3.9. Balanced One-Way ANOVA for Four Sediment Treatments Using the Arc Sine (Expressed in Radians) Square Root of the Proportion of R. abronius Surviving a 10-Day, Solid-Phase Static Exposure

\begin{tabular}{|c|c|c|c|c|c|}
\hline $\begin{array}{l}\text { Source of } \\
\text { Variation }\end{array}$ & $\begin{array}{l}\text { Sum of } \\
\text { Squares }\end{array}$ & D.F. & $\begin{array}{c}\text { Mean } \\
\text { Square }\end{array}$ & F-Ratio & $\begin{array}{c}\begin{array}{c}\text { Significance } \\
\text { Level }\end{array} \\
\end{array}$ \\
\hline Between groups & 0.741 & 3 & 0.247 & 12.374 & 0.0002 \\
\hline Within groups & 0.299 & 15 & 0.020 & & \\
\hline Total & 1.040 & 18 & & & \\
\hline
\end{tabular}

\section{Comparison of Percent Survival: Amphipod (G. japonica)}

The mean proportions of $\underline{G}$. japonica surviving both the flow-through and static 10-day bioassays for the four sediment treatments are presented in Tables 3.10 and 3.11 , respectively. One-way ANOVA among all sediment treatments of each test using the angular transformed data was not significant $(\alpha=0.05)$ in either case (Tables 3.12 and 3.13). Tukey's HSD multiple 
comparison procedure classifies all sediment treatments into the same statistica) groups (Tables 3.10 and 3.11). This shows that there was no significant difference in the mean proportion of $\underline{G}$. japonica surviving the four treatments in either the flow-through or static test.

IABLE 3.10. Proportion of Amphipods (G. japonica) Surviving After 10-Day Flow-Through Exposure to Four Sediment Treatments and Comparison of the Means

\begin{tabular}{|c|c|c|c|}
\hline $\begin{array}{l}\text { Sediment } \\
\text { Treatment } \\
\end{array}$ & $\begin{array}{l}\quad \text { Mean } \\
\text { Proportion } \\
\text { Surviving }\end{array}$ & $\begin{array}{l}\text { Standard } \\
\text { Deviation }\end{array}$ & $\begin{array}{r}\text { Statistjoal } \\
\text { Group }\end{array}$ \\
\hline DS & 0.96 & 0.042 & $A$ \\
\hline WB & 0.99 & 0.022 & A \\
\hline C1 & 0.94 & 0.089 & A \\
\hline $\mathrm{C} 2$ & 0.94 & 0.065 & A \\
\hline
\end{tabular}

(a) Treatments within the same statistical group are not significantly $(\alpha=0.05)$ different (Tukey's HSD multiple comparison).

TABLE 3.11. Proportion of Amphipods (G. japonica) Surviving After 10-Day Static Exposure to Four Sediment Treatments and Comparison of the Means

\begin{tabular}{|c|c|c|c|}
\hline $\begin{array}{l}\text { Sed iment } \\
\text { Treatment } \\
\end{array}$ & $\begin{array}{l}\text { Mean } \\
\text { Proportion } \\
\text { Surviving }\end{array}$ & $\begin{array}{l}\text { Standard } \\
\text { Deviation }\end{array}$ & $\begin{array}{r}\text { Stat istjoal } \\
\text { Group }(a)\end{array}$ \\
\hline$R$ & 0.96 & 0.055 & A \\
\hline WB & 0.95 & 0.050 & $A$ \\
\hline $\mathrm{Cl}$ & 0.84 & 0.180 & $A$ \\
\hline $\mathrm{C} 2$ & 0.84 & 0.139 & A \\
\hline
\end{tabular}

(a) Treatments within the same statistical group are not significantly $(\alpha=0.05)$ different (Tukey's HSD multiple comparison). 
TABLE 3.12. Balanced One-Way ANOVA for Four Sediment Treatments Using the Arc Sine (Expressed in Radians) Square Root of the Proportion of G. japonica Surviving a 10-Day, Solid-Phase, Flow-Through Exposure

\begin{tabular}{|c|c|c|c|c|c|}
\hline $\begin{array}{l}\text { Source of } \\
\text { Variation }\end{array}$ & $\begin{array}{l}\text { Sum of } \\
\text { Squares }\end{array}$ & D.F. & $\begin{array}{c}\text { Mean } \\
\text { Square }\end{array}$ & F-Ratio & $\begin{array}{l}\text { Significance } \\
\text { Level }\end{array}$ \\
\hline Between groups & 0.059 & 3 & 0.020 & 0.694 & 0.5690 \\
\hline Within groups & 0.456 & 16 & 0.028 & & \\
\hline Total & 0.515 & 19 & & & \\
\hline
\end{tabular}

IABLE 3.13. Balanced One-Way ANOVA for Four Sediment Treatments Using the Arc Sine (Expressed in Radians) Square Root of the Proportion of $\mathrm{G}$. japonica Surviving a 10-Day, Solid-Phase, Flow-Through Exposure

\begin{tabular}{|c|c|c|c|c|c|}
\hline $\begin{array}{l}\text { Source of } \\
\text { Variation }\end{array}$ & $\begin{array}{l}\text { Sum of } \\
\text { Squares }\end{array}$ & D.F. & $\begin{array}{c}\text { Mean } \\
\text { Square }\end{array}$ & F-Ratio & $\begin{array}{l}\text { Significance } \\
\text { Level }\end{array}$ \\
\hline Between groups & 0.236 & 3 & 0.078 & 1.908 & 0.1716 \\
\hline Within groups & 0.617 & 15 & 0.041 & & \\
\hline Total & 0.853 & 18 & & & \\
\hline
\end{tabular}

We conclude that because of the high proportions of survival in the Disposal Site $F$ (DS) and West Beach (WB) reference sediments, both G. japonica and $\underline{R}$. abronius are suitable bioassay animals for estimating sediment toxicity.

\subsection{CHEMICAL ANALYSIS OF DREDGED-MATERIAL SAMPLES}

\subsubsection{Priority Pollutant Polynuclear Aromatic Hydrocarbons (PAHs), Pesticides, and Polychlorinated Biphenyls (PCBs)}

One pesticide and 10 PAHs were either above the detection limits established for these studies or, if below, were considered present by the analyst in both Tongue Point composites (Table 3.14 and Appendix B). No PCB aroclors were detected or considered present at Tongue Point, and none of these contaminants were detected at Disposal Site $F$ or West Beach. The pesticide $4,4^{\prime}$ DDD was below the calculated detection limit but considered real in both composites at concentrations of 1.9 and $2.4 \mu \mathrm{g} / \mathrm{kg}$ dry wt in $\mathrm{Cl}$ and $\mathrm{C2}$, respectively. 
TABLE 3.14. Polynuclear Aromatic Hydrocarbons, Phthalates, and Pesticides Detected or Considered Present in Tongue Point Composited Sediments

\begin{tabular}{|c|c|c|}
\hline Organic Compound & $\frac{C l}{C l}$ & $\frac{\ln / \mathrm{kn}}{\mathrm{C2}}$ \\
\hline Phenanthrene & $55^{(a)}$ & $48^{(a)}$ \\
\hline Fluoranthene & 110 & 93 \\
\hline Pyrene & 150 & 150 \\
\hline Benzo(a)Anthracene & $68^{(a)}$ & 62 \\
\hline Crysene & 110 & 97 \\
\hline 8enzo(b/k)Fluoranthene & 160 & $140^{(a)}$ \\
\hline Benzo(a)Pyrene & 66 & 95 \\
\hline Indeno $(1,2,3-c d)$ Pyrene & 160 & 110 \\
\hline Benzo(ghi)Perylene & $180^{(a)}$ & $140^{(a)}$ \\
\hline bis(2-Ethy?hexyl)Phthalate & -- & $78^{(a)}$ \\
\hline $4,4^{\prime}-\mathrm{DDD}$ & $1.9^{(b)}$ & $2.4^{(b)}$ \\
\hline
\end{tabular}

(a) Compound was present but below detection limit and peak was not quantifiable. Estimated amount of analyte found and confirmed by analyst, but with low spectral match parameter.

(b) Indicates quantifiable value below the calculated detection limit, but considered real by analyst.

Measured PAHs totaled $1059 \mu \mathrm{g} / \mathrm{kg}$ in $\mathrm{Cl}$ and $1013 \mu \mathrm{g} / \mathrm{kg}$ in $\mathrm{C2}$. The total PAHs observed were composed primarily of fluoranthene, pyrene, benzo(a)anthracene, chrysene, benzo(b,k)-fluoranthene, indeno(1,2,3-cd)pyrene, and benzo(a)pyrene. Bis(2-Ethylhexyl)phthalate was considered present in $\mathrm{C2}$, but not in $\mathrm{Cl}$, and was the only phthalate ester encountered.

\subsubsection{Metals and Metalloids}

Table 3.15 shows the dry weight concentrations of eight metal and metalloid contaminants in the Tongue Point composites, the reference sediment from Disposal Site $F$, and the West Beach sediment. Chemical contaminant concentrations of reference and test sediments were compared by dividing the concentration in each test sediment treatment by the reference sediment 
IABLE 3.15. Concentrations of Metals in the Four Sediment Treatments and Average Crustal Abundance of Metals in Shale and Basalt Soils Throughout the World

\begin{tabular}{|c|c|c|c|c|c|c|c|c|}
\hline \multirow[b]{2}{*}{ Treatment } & \multicolumn{8}{|c|}{ Metal Concentrations, $\mathrm{mg} / \mathrm{kg}$ dry wt } \\
\hline & As & $\mathrm{Cd}$ & $\mathrm{Cr}$ & $\mathrm{Cu}$ & $\mathrm{Hg}$ & $\mathrm{Ni}$ & $\mathrm{Pb}$ & Zn \\
\hline DS & 2.29 & 0.05 & 19.2 & 8.38 & 0.007 & 17.9 & 6.42 & 73.0 \\
\hline WB & 1.87 & 0.06 & 17.4 & 7.49 & 0.005 & 26.5 & 1.43 & 51.5 \\
\hline $\mathrm{Cl}$ & 5.43 & 1.16 & 25.0 & 30.8 & 0.143 & 23.0 & 18.38 & 134.6 \\
\hline C2 & 5.18 & 1.21 & 22.8 & 35.1 & 0.160 & 22.4 & 20.52 & 161.8 \\
\hline Shate soil & 6.6 & 0.30 & 100.0 & 57.0 & 0.4 & 95 & 20 & 80 \\
\hline Basalt soils & 2.0 & 0.2 & 200.0 & 100.0 & 0.0 & 150 & 5 & 100 \\
\hline
\end{tabular}

concentration. Results of this process are presented in Table 3.16 for Disposal Site $F$ and for West Beach in Table 3.17. Comparisons also were made between the average crustal abundance of the metals and metalloids found in shale soils and basalt soils (Krauskopf 1967) throughout the world as a basis of reference to relative contaminant loads (Table 3.15). With the exception of zinc and cadmium in the Tongue Point composites, all metal concentrations in the sediment treatments were less than or comparable to the average concentrations seen in shale soils found worldwide. C2, with the higher level of zinc, had a concentration only 2.02 times that of the average shale soil concentration. Tongue Point composites $\mathrm{Cl}$ and $\mathrm{C} 2$ exceeded the concentrations reported for basalt soils for $\mathrm{As}, \mathrm{Cd}, \mathrm{Hg}, \mathrm{Pb}$, and $\mathrm{Zn}$, and were less than reported values for $\mathrm{Cr}, \mathrm{Cu}$, and $\mathrm{Ni}$. The hignest enhancement occurred with respect to $C d$, where sediment treatment $C 2$ was almost six times the concentration of the basalt soil.

The basalt soil comparison may be the most informative, since it is the most common rock formation in the Columbia Basin. However, except for chromium and nickel, metals in the Tongue Point sediments were generally enriched when compared with levels in the reference sediments. Cadmium was at least 19 times higher, and mercury was at ieast 20 times and up to 32 times the concentrations in the reference sediments. 
IABLE 3.16. Comparison of Metal Concentration for Each Sediment Treatment Relative to Metal Concentration at Reference Site (Disposal Site F)

\begin{tabular}{|c|c|c|c|c|c|c|c|c|}
\hline & \multicolumn{8}{|c|}{ Metal Concentration Ratios } \\
\hline Treatment & As & $c d$ & $\mathrm{Cr}$ & $\mathrm{Cu}$ & $\mathrm{Hg}$ & $\mathrm{Ni}$ & $\mathrm{Pb}$ & $\mathrm{Zn}$ \\
\hline $\mathrm{Cl}$ & 2.4 & 23.2 & 1.3 & 3.7 & 20.4 & 1.3 & 2.9 & 1.8 \\
\hline c2 & 2.2 & 24.2 & 1.2 & 4.2 & 22.9 & 1.3 & 3.2 & 2.2 \\
\hline
\end{tabular}

TABLE 3.17. Comparison of Metal Concentration for Each Sediment Treatment Relative to Metal Concentration at Reference Site (West Beach, Washington)

\begin{tabular}{|c|c|c|c|c|c|c|c|c|}
\hline \multirow[b]{2}{*}{ Treatment } & \multicolumn{8}{|c|}{ Metal Concentration Ratios } \\
\hline & As & $c d$ & $\mathrm{Cr}$ & Cu & $\mathrm{Hq}$ & $\mathrm{Ni}$ & $\mathrm{Pb}$ & $\mathrm{Zn}$ \\
\hline Cl & 2.9 & 19.3 & 1.4 & 4.1 & 28.6 & 0.86 & 12.8 & 2.6 \\
\hline $\mathrm{C2}$ & 2.8 & 20.2 & 1.3 & 4.7 & 32.0 & 0.84 & 14.3 & 3.1 \\
\hline
\end{tabular}

\subsubsection{Total Organic Carbon}

Total organic carbon (TOC) in both composites of the Tongue Point sediments was higher than in the two reference sediments (Table 3.18). The highest enrichment was in $\mathrm{C2}, 8.45$ times the concentration in the Disposal Site sediment and 11.62 times that in west Beach sediment.

\subsubsection{0j1 and Grease}

Table 3.19 presents the dry weight concentrations of $0 i 1$ and grease at Tongue Point, Disposal Site $F$, and West Beach. $0 i 1$ and grease in $\mathrm{Cl}$ was 9.14 times that in the Disposal Site sediment.

\subsubsection{Petroleum Hydrocarbons}

Removal of the fatty acid portion of the oil and grease contaminants with silica gel provides information on the petroleum hydrocarbon fraction of $0 i 1$ and grease. Table 3.19 shows that petroleum hydrocarbons were less than detectable in the reference sediments and $23.0 \mathrm{mg} / \mathrm{kg}$ in both Tongue Point composites. 
TABLE 3.18. Concentration and Enrichment Factors of TOC from Tongue Point Disposal Site $F$, and West Beach

Sediment
Ireatment

DS

WB

$\mathrm{Cl}$

C2
Total Organic Carbon, $\%$ dry wt
0.11
0.08
0.80
0.93

Enrichment Factors Disposal Site $F$ West Beach 1.38

0.72

7.27

10.00

8.45

11.62

TABLE 3.19. Conventionals/Petroleum Hydrocarbons in Sediments, dry wt

\begin{tabular}{|c|c|c|c|c|}
\hline $\begin{array}{l}\text { Sediment } \\
\text { Ireatment }\end{array}$ & $\begin{array}{c}0 i 1 \& \text { Grease, } \\
\mathrm{mg} / \mathrm{kg}\end{array}$ & $\begin{array}{c}\text { Petroleum } \\
\text { Hydrocarbons, } \\
\mathrm{mg} / \mathrm{kg} \\
\end{array}$ & $\begin{array}{l}\text { Dissolved } \\
\text { Sulfides, } \\
\mathrm{mg} / \mathrm{kg} \\
\end{array}$ & $\begin{array}{c}\text { Ammonia } \\
\text { Nitrogen, } \\
\text { mg } / \mathrm{kg} \\
\end{array}$ \\
\hline DS & 6.3 & $<5.0$ & 11.6 & 47.5 \\
\hline$W B$ & 8.6 & $<5.0$ & 62.4 & $<14.0$ \\
\hline $\mathrm{Cl}$ & 57.6 & 23.0 & 93.8 & 131 \\
\hline $\mathrm{C} 2$ & 52.8 & 23.0 & 11.6 & 105 \\
\hline
\end{tabular}

\subsubsection{Dissolved Sulfides and Ammonia}

Dissolved sulfides and ammonia were determined from aliquots of preserved sediment (Table 3.19). Sulfides ranged from 11.6 to $93.8 \mathrm{mg} / \mathrm{kg}$ dry wt, and ammonia ranged from less than detectable in west Beach sediments to $131 \mathrm{mg} / \mathrm{kg}$ in $\mathrm{Cl}$ from Tongue Point.

\subsubsection{Grain Size and Total Solids}

A detailed grain size analysis was performed on each sediment treatment with size fractions divided into 16 phi-size categories (Appendix B). Percentages of major size fractions (gravel, sand, silt, and clay) are presented in Table 3.20 along with the percentage of total solids. The reference sediments were $96 \%$ or higher in sand, whereas Tongue Point sediments were at least $50 \%$ silt, about 30 to $40 \%$ sand, and at least $10 \%$ clay. Total solids were between 10 and $20 \%$ greater in the reference sediments. 
TABLE 3.20. Sediment Grain Size and Total Solids

\begin{tabular}{|c|c|c|c|c|c|}
\hline $\begin{array}{l}\text { Sediment } \\
\text { Ireatment }\end{array}$ & $\begin{array}{c}\text { Total } \\
\text { Solids, \% }\end{array}$ & $\begin{array}{l}\% \text { Gravel, } \\
\geq 2.00 \mathrm{~mm}\end{array}$ & $\begin{array}{c}\% \text { Sand, } \\
0.063-2.00 \mathrm{~mm}\end{array}$ & $\begin{array}{c}\% \text { Silt, } \\
0.004-0.063 \mathrm{~mm}\end{array}$ & $\begin{array}{r}\% \text { Clay, } \\
\leq 0.004 \mathrm{~mm}\end{array}$ \\
\hline DS & 78.13 & 0.0 & 96.19 & 1.66 & 2.15 \\
\hline WB & 76.30 & 0.0 & 98.02 & 0.36 & 1.63 \\
\hline C1 & 63.44 & 0.0 & 39.22 & 50.23 & 10.56 \\
\hline C2 & 60.68 & 0.0 & 29.14 & 58.00 & 12.87 \\
\hline
\end{tabular}




\section{-}




\subsection{CONCLUSIONS}

\subsection{SOLID-PHASE BIOASSAYS}

All solid-phase bioassays had less than $10 \%$ mortality in the reference or control sediments over the 10- and 20-day periods. Therefore, according to requirements in the Implementation Manual (EDA/USACE 1977), all these tests are valid experiments. Only one test, $\underline{\mathrm{R}}$ abronius (static), showed statistically significant differences between reference or control samples and test sediments (Table 4.1). That test also showed greater than $10 \%$ mortality from controls which, according to the Implementation Manual criteria, requires prediction of the probable impact of the disposal of this material. Survival of $\underline{\mathbf{R}}$ abronius in replicates of the test sediments ranged from 60 to $95 \%$ with a mean of $76 \%$ in $\mathrm{Cl}$ and 70 to $90 \%$ with a mean of $84 \%$ in C2. The variability of survival in that test may indicate a possible patchiness to the toxicity even though the composited sediment samples appeared homogeneous. Further evaluation of amphipod bioassays reveals that under flow-through conditions survival of $\underline{R}$. abronius in the test sediments was not significantly different from survival in control or reference sediments. It is anticipated that during actual disposal of Tongue Point material seawater flow will dilute the sediment by sweeping away contaminants during its fall to the sea floor, minimizing acute effects. This phenomenon is better reflected in the flow-through bioassay where the moving water dilutes water-soluble contaminants, than it is in the static test where contaminants are less readily removed.

TABLE 4.1. Significant Differences in Surviva? Among Bioassay Treatments

\section{Bioassay}

N. caecoides/M. nasuta (10-day)

M. nasuta (20-day)

R. abronius (static)

R. abronius (flow-through)

G. japonica (static)

G. japonica (flow-through)
Significant Differences

in Survival

None

None

Yes $(76-84 \%)$

None

None

None 


\subsection{CHEMICAL TRENDS}

The Tongue Point sediment contained detectable concentrations of nine polynuclear aromatic hydrocarbons, one phthalate, and one pesticide (Table 4.2). Two metals, $\mathrm{Cd}$ and $\mathrm{Hg}$, were enriched more than twentyfold in

TABLE 4.2. Sumnary of Sediment Characterization and Contaminant

Enrichment in Tongue Point Sediments Relative to

Reference Sediments

Contaminant $(a)$

Average Concentration Ratio (b)

Metals

$\begin{array}{lrccc}\text { As } & 2.3 & 2.9 & 0.8 & 2.7 \\ \mathrm{Cd} & 23.7 & 19.8 & 4.0 & 5.9 \\ \mathrm{Cr} & 1.3 & 1.4 & 0.24 & 0.1 \\ \mathrm{Cu} & 2.1 & 4.4 & 0.58 & 0.3 \\ \mathrm{Hg} & 21.7 & 30.3 & 0.38 & \mathrm{ND}(\mathrm{c}) \\ \mathrm{Ni} & 1.3 & 0.85 & 0.24 & 0.2 \\ \mathrm{~Pb} & 3.1 & 13.6 & 0.97 & 3.9 \\ \mathrm{Zn} & 2.0 & 2.9 & 1.9 & 1.5 \\ \text { Oi1 \& Grease } & 8.8 & 6.4 & \text { ND } & \text { ND } \\ \text { Petrolelim Hydrocarbon } & -5 & -5 & \text { ND } & \text { ND } \\ \text { Ammonia Nitrogen } & 2.5 & -8 & \text { ND } & \text { ND } \\ \text { Dissolved Sulfide } & 6.6 & -(d) & \text { ND } & \text { ND }\end{array}$

(a) Pesticides and PAHs in reference sediments were below detection, so a concentration ratio could not be generated.

(b) Determined by

$\frac{c 1}{\text { reference site concentration }}+\frac{c 2}{\text { reference site concentration }} / 2$

where reference site is Disposal Site F or West Beach.

(c) $\mathrm{ND}=$ not determined.

(d) West Beach sulfide value was suspiciously high, probably an analytical error. 
the test sediments when compared with sediment from Disposal Site $F$. In addition, $\mathrm{Pb}$ was enriched more than tenfold when compared with sediment from West Beach. $0 i 1$ and grease, petroleum hydrocarbons, amnonia nitrogen, and dissolved sulfides were also enriched between three and nine times more at Tongue Point than is compared to the reference sediment.

\subsection{BIOACCUMULATION}

There was no statistically significant increase in the bioaccumulation of metals or PAHs in $\underline{M}$. nasuta exposed to Tongue Point sediments when compared with clams exposed to Disposal site F sediments. Only the pesticide 4,4'-DDD was concentrated in clams from the Tongue Point sediments to a degree that was above the analytical detection limits. This pesticide was undetectable in clams from the Disposal Site $F$ treatment. Low levels of Aroclor-1254 and $4,4^{\prime}$-DDE also were measured in clams from the test sediments but were below the calculated detection limit. 



\subsection{REFERENCES}

American Public Health Association (APHA). 1985. Standard Methods for the Examination of Water and Wastewater. 16th ed. American Public Health Association (APHA), Anerican Water Works Association (AWWA), Water Pollution Control Federation (WPCF), p. 1268.

American Society for Testing and Materials (ASTM). 1980a. Standard Practice for Conducting Acute Toxicity Tests with Fishes, Macroinvertebrates, and Amphibians. E729-80, pp. 272-295. American Society for Testing and Materials, Philadelphia, Pennsylvania.

American Society for Testing and Materials (ASTM). 1980b. Standard Practice for Conducting Static Acute Toxicity Tests with Larvae of Four Species of Bivalve Molluscs. E724-80. American Society for Testing and Materials, Philadelphia, Pennsylvania.

Federal Register. 1977. "Ocean Dumping. Final Revisions of Regulations." Fed. Reg. Part VI, Vol. 42, No. 7.

Green, E. J., and D. Schnitker. 1974. "The Direct Titration of WaterSoluble Sulfide in Estuarine Muds of Montsweag Bay, Maine." Marine Chem. 2:111-124.

Krauskopf, K. 1967. Introduction to Geochemistry. McGraw-Hill, New York.

Puget Sound Estuary Program (PSEP). 1986. Recommended Protocols for Measuring Selected Environmental Variables in Puget Sound. Volumes 1 and 2. Prepared by Tetra-Tech, Inc. for the Puget Sound Estuary Program. Bellevue, Washington.

Standard Methods. 1975. Standard Methods for the Examination of Water and Wastewater. 14th ed. American Public Health Association (APHA), American Water Works Association (AWWA), Water Pollution Control Federation (WPCF). Washington, D.C. p. 1193.

Steel, R. G. D., and J. H. Torrie. 1980. Principles and Procedures of Statistics. A Biometrical Approach. McGraw-Hill, New York.

U.S. Environmental Protection Agency (EPA). 1976. Bioassay Procedures for the Ocean Disposal Permit Program. EPA-600/9-76-010, Environmental Research Laboratory, Office of Research and Development, Gulf Breeze, Florida.

U.S. Environmenta1 Protection Agency (EPA). 1978. Bioassay Procedures for the Ocean Disposal Permit Program. EPA-600/9-7B-10, Environmental Research Laboratory, Office of Research and Development, Gulf Breeze, Florida. 
U.S. Environmental Protection Agency (EPA). 1988. Laboratory Data Validation Functional Guidelines for Evaluating Organics Analyses. EPA-R-582-5-501, Hazardous Site Evaluation Division, Washington, D.C.

U.S. Environmental Protection Agency/Corps of Engineers Technical Committee on Criteria for Dredged and Fill Material (EPA/USACE). 1977. Ecological

Evaluation of Proposed Discharge of Dredged Material into Ocean Waters:

Implementation Manual for Section 103 of Pub7ic Law 92-532 (Marine Protection, Research, and Sanctuaries Act of 1972). Environmental Effects Laboratory, U.S. Army Engineer Waterways Experiment Station, Vicksburg, Mississippi.

U.S. Environmenta? Protection Agency (EPA). 1979. Methods for Chemical Analys is of Water and Wastes. EPA-600 4-79-020, Environmental Monitoring and Support Laboratory, Cincinnati, Ohio.

U.S. Environmental Protection Agency (EPA). 1986. Test Methods for Evaluating Solid Waste: Physical/Chemical Methods. EPA-955-001-00000, Government Printing Office, Washington, D.C.

Word, J. Q., W. H. Pearson, J. R. Skalski, J. M. Gurtisen, R. B. Lucke and J. A. Strand. 1987. Reconnaissance of Petroleum Contamination from the ARCO ANCHORAGE 0i] Spill at Port Angeles, Washington, and Its Influence on Selected Areas of the Strait of Juan de Fuca. Batteile/Marine Research Laboratory, Sequim, Washington. 
APPENDIX A

SAMPLING AND SAMPLE COMPOSITE INFORMATION 
APPENDIX A

\section{SAMPLING AND SAMPLE COMPOSITE INFORMATION}

TABLE A.1. Sediment Compositing Information

Grab

Measurement or Test Type

Station Number Composite Bioaccumulation Organics Metals Conventionals

3

3

4

4

5

5

6

6

6

5

$7 \quad 1$ Archived

$7 \quad 2$ Archived

$\begin{array}{lll}7 & 3 & \mathrm{Cl}\end{array}$

$\begin{array}{llll}7 & 4 & \mathrm{Cl}\end{array}$

WB 1 WB ${ }^{(a)}$

Ref 1-5 Ref

$\begin{array}{llll}x & x & x & x \\ x & x & x & x\end{array}$

(a) M. nasuta bioaccumulation and bioassay tests not performed using West Beach coarse-grained sediment control. 
,

. 
APPENDIX B

SEDIMENT PHYSICAL AND CHEMICAL DATA SUMMARY 


\section{APPENDIX B}

\section{SEDIMENT PHYSICAL AND CHEMICAL DATA SUMMARY}

TABLE B.1. Polynuclear Aromatic Hydrocarbons (PAHs) Analyzed and Average Detection Limits for Each

\begin{tabular}{lr}
\multicolumn{1}{c}{ PAHs Analyzed } & $\begin{array}{c}\text { Detection } \\
\text { Limit, } \\
\mu \mathrm{g} / \mathrm{kg}\end{array}$ \\
\hline Phenol & $67 \mathrm{U}$ \\
bis(2-Chloroethyl)Ether & $67 \mathrm{U}$ \\
2-Chlorophenol & $67 \mathrm{U}$ \\
1,3-Dichlorobenzene & $67 \mathrm{U}$ \\
1,4-Dichlorobenzene & $67 \mathrm{U}$ \\
Benzyl Alcohol & $330 \mathrm{U}$ \\
1,2-Dichlorobenzene & $67 \mathrm{U}$ \\
1-Methylphenol & $67 \mathrm{U}$ \\
bis(2-chloroisopropyl)Ether & $67 \mathrm{U}$ \\
4-Methylphenol & $67 \mathrm{U}$ \\
N-Nitroso-Di-n-Propylamine & $67 \mathrm{U}$ \\
Hexachloroethane & $130 \mathrm{U}$ \\
Nitrobenzene & $67 \mathrm{U}$ \\
Isophorone & $67 \mathrm{U}$ \\
2-Nitrophenol & $330 \mathrm{U}$ \\
2,4-Dimethylphenol & $130 \mathrm{U}$ \\
Benzoic Acid & $670 \mathrm{U}$ \\
Bis(2-Chloroethoxy)Methane & $67 \mathrm{U}$ \\
2m4-Dichlorophenol & $200 \mathrm{U}$ \\
1,2,4-Trichlorobenzene & $67 \mathrm{U}$ \\
Naphthalene & $67 \mathrm{U}$ \\
4-Chloroaniline & $200 \mathrm{U}$ \\
Hexachlorobutadiene & $130 \mathrm{U}$ \\
4-Chloro-3-Methylphenol & $130 \mathrm{U}$ \\
2-Methylnaphthanene & $67 \mathrm{U}$ \\
Hexachlorocyclopentadiene &
\end{tabular}

B. 1 
TABLE B.1. (contd)

\begin{tabular}{lrl}
\multicolumn{1}{c}{ PAHs Analyzed } & $\begin{array}{c}\text { Detection } \\
\text { Limit, } \\
\mu \mathrm{kg} / \mathrm{kg}\end{array}$ \\
\hline 2,4,6-Trichlorophenol & $330 \mathrm{U}$ \\
2,4,5-Trichlorophenol & $330 \mathrm{U}$ \\
2-Chloronaphthalene & $67 \mathrm{U}$ \\
2-Nitroaniline & $330 \mathrm{U}$ \\
Dimethyl Phthalate & $67 \mathrm{U}$ \\
Acenaphthylene & $67 \mathrm{U}$ \\
3-Nitroaniline & $330 \mathrm{U}$ \\
Acenaphthene & $67 \mathrm{U}$ \\
2,4-Dinitrophenol & $670 \mathrm{U}$ \\
4-Nitrophenol & $330 \mathrm{U}$ \\
Dibenzofuran & $67 \mathrm{U}$ \\
2,4-Dinitrotoluene & $330 \mathrm{U}$ \\
2,6-Dinitrotoluene & $330 \mathrm{U}$ \\
Diethylphthatate & $67 \mathrm{U}$ \\
4-Chlorophenyl-phenylether & $67 \mathrm{U}$ \\
Fluorene & $67 \mathrm{U}$ \\
4-Nitroaniline & $330 \mathrm{U}$ \\
4,6-Dinitro-2-Methylphenol & $670 \mathrm{U}$ \\
N-Nitrosodiphenylamine (a) & $67 \mathrm{U}$ \\
4-Bromophenyl-phenylether & $67 \mathrm{U}$ \\
Hexachlorobenzene & $67 \mathrm{U}$ \\
Pentachlorophenol & $330 \mathrm{U}$ \\
Phenanthrene & $67 \mathrm{U}$ \\
Anthracene & $67 \mathrm{U}$ \\
Di-n-Butylphthalate & $67 \mathrm{U}$ \\
Fluoranthene & $67 \mathrm{U}$ \\
Pyrene & $67 \mathrm{U}$ \\
Butylbenzylphthalate & $67 \mathrm{U}$ \\
3,3'-Dichlorobenzidine & $330 \mathrm{U}$ \\
&
\end{tabular}

(a) Cannot be separated from diphenyiamine. 
TABLE B.1. (contd)

PAHs Analyzed

Benzo(a)Anthracene

bis(2-Ethylhexy1)Phthalate

Chrysene

Di-n-Octyl Phthalate

Benzo(b)Fluoranthene

Benzo(k)Fluoranthene

Benzo(a)Pyrene

Ideno(1,2,3-cd) Pyrene

Dibenz ( $a, h)$ Anthracene

Benzo(ghi)Perylene

Base/neutral Surrogate Recoveries (a)

d5-Nitrobenzene

2-Fluorobiphenyl

d14-p-Terpheny?

Acid Surrogate Recoveries (a)

d5-Phenol

2-Fluorophenol

2, 4,6-Tribromophenol
Detection

Limit, $\mu \mathrm{g} / \mathrm{kg}$

$67 \mathrm{U}$

$67 \mathrm{U}$

$67 \mathrm{U}$

$67 \mathrm{U}$

$67 \mathrm{U}$

$67 \mathrm{U}$

$67 \mathrm{U}$

$67 \mathrm{U}$

$67 \mathrm{U}$

$67 \mathrm{U}$

$57.4 \%$

$60.8 \%$

$79.1 \%$

$59.0 \%$

$60.4 \%$

$53.4 \%$

(a) The base/neutral and acid surrogate recoveries are within acceptable ranges specified by USEPA Contract Laboratory Procedures (CLP) Guidelines, Section III Volatiles QA/QC Requirements (EPA 1988). 
IABLE B.2. Pesticides and PCBs Analyzed and Average Detection Limits for Each

\begin{tabular}{|c|c|}
\hline Pesticides Analyzed & $\begin{array}{c}\text { Detection } \\
\quad \text { Limit, } \\
\mu \mathrm{g} / \mathrm{kg} \\
\end{array}$ \\
\hline A]pha-BHC & $2.0 \mathrm{U}$ \\
\hline Beta-BHC & $2.0 \mathrm{U}$ \\
\hline Delta-BHC & $2.0 \mathrm{U}$ \\
\hline Gamma-BHC (Lindane) & $2.0 \mathrm{U}$ \\
\hline Heptachlor & $2.0 \mathrm{U}$ \\
\hline Aldrin & $2.0 \mathrm{U}$ \\
\hline Heptachlor Epoxide & $2.0 \mathrm{U}$ \\
\hline Eldosulfan I & $6.0 \mathrm{U}$ \\
\hline Dieldrin & $4.0 \mathrm{U}$ \\
\hline $4,4^{\prime}-\mathrm{DDE}$ & $4.0 \mathrm{U}$ \\
\hline Endrin & $4.0 \mathrm{U}$ \\
\hline Endosulfan II & $4.0 \mathrm{U}$ \\
\hline $4,4^{\prime}-D D D$ & 4.1 \\
\hline Endolsulfan Sulfate & $4.0 \mathrm{U}$ \\
\hline $4,4^{\prime}-\mathrm{DDT}$ & $4.0 \mathrm{U}$ \\
\hline Methoxychlor & $8.0 \mathrm{U}$ \\
\hline Endrin Ketone & $4.0 \mathrm{U}$ \\
\hline Chlordane & $20 U$ \\
\hline Toxaphene & $200 \mathrm{U}$ \\
\hline Arocior -1016 & $40 \mathrm{U}$ \\
\hline Aroclor- 1242 & $40 \mathrm{U}$ \\
\hline Aroclor -1248 & $40 \mathrm{U}$ \\
\hline Aroclor -1248 & $40 \mathrm{U}$ \\
\hline Arocior- 1260 & $40 \mathrm{U}$ \\
\hline \multicolumn{2}{|c|}{ Pesticide Surrogate Recovery } \\
\hline Dibutylchlorendate & $82 \%$ \\
\hline
\end{tabular}


TABLE B.3. Detected Polynuclear Aromatic Hydrocarbons, Phthalates, Polychiorinated Biphenyls, Pesticides

\begin{tabular}{|c|c|c|c|c|}
\hline Contaminant & $\mathrm{Cl}$ & $\mathrm{C} 2$ & DS & WB \\
\hline \multicolumn{5}{|l|}{ Organics } \\
\hline Phenanthrene & $55 \mathrm{M}$ & $48 M$ & $53 \mathrm{U}$ & $58 \mathrm{U}$ \\
\hline Fluoranthrene & 110 & 93 & $53 \mathrm{U}$ & $58 \mathrm{U}$ \\
\hline Pyrene & 150 & 150 & $53 \mathrm{U}$ & $58 \mathrm{U}$ \\
\hline Benzo(a)Anthracene & $68 \mathrm{M}$ & 62 & $53 \mathrm{U}$ & $58 \mathrm{U}$ \\
\hline bis(1-Ethylhexyl)Phthalate & $57 \mathrm{U}$ & $78 M$ & $63 \mathrm{U}$ & $58 \mathrm{U}$ \\
\hline Chrysene & 110 & 97 & $53 \mathrm{U}$ & $58 \mathrm{U}$ \\
\hline Benzo $(b, k) F l u o r a n t h e n e$ & 160 & $140 \mathrm{M}$ & $53 \mathrm{U}$ & $58 \mathrm{U}$ \\
\hline Benzo(a)Pyrene & 66 & 95 & $53 \mathrm{U}$ & $58 \mathrm{U}$ \\
\hline Ideno $(1,2,3$-cd $)$ Pyrene & 160 & 119 & $53 \mathrm{U}$ & $58 \mathrm{U}$ \\
\hline Benzo(ghi)Perylene & $180 \mathrm{M}$ & $140 \mathrm{M}$ & $53 \mathrm{U}$ & $58 \mathrm{U}$ \\
\hline \multicolumn{5}{|l|}{ Pesticides/PCBs } \\
\hline $4.4^{\prime}-\mathrm{DDE}$ & $4.0 \mathrm{U}$ & $4.0 \mathrm{U}$ & 4.00 & $4.0 \mathrm{U}$ \\
\hline $4.4^{\prime}-\mathrm{DDD}$ & $1.9 \mathrm{~J}$ & $2.4 \mathrm{~J}$ & $4.0 \mathrm{U}$ & $4.0 \mathrm{U}$ \\
\hline $4.4^{\prime}-\mathrm{DDT}$ & $4.0 \mathrm{U}$ & $4.0 \mathrm{U}$ & 4.00 & $4.0 \mathrm{U}$ \\
\hline Aroclor & $40 \mathrm{U}$ & $40 \mathrm{U}$ & $40 U$ & $40 U$ \\
\hline
\end{tabular}

$U$ Indicates compound was analyzed for but not detected at given detection limit.

J Indicates quantifiable value below the calculated detection rimit but considered real by analyst.

$M$ Compound was present but below detection limit and peak was not quantifiable. Estimate of analyte made and confirmed by analyst, but with low spectral match parameter. 
TABLE B.4. Percent of Surrogate Recoveriew for Analytical Chemistry QA/QC

Surrogate Types

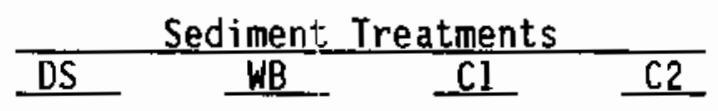

Base/Neutrals

d5-Nitrobenzene

80.6

78.8

86.5

72.2

2-FTuorbiphenyl

75.1

77.9

85.2

73.2

dl4-p-Terphenyl

83.5

82.4

88.5

84.4

Acids

d5-Phenol

79.4

79.8

85.1

75.4

2-Fluorophenol

85.1

87.1

86.6

80.5

2, 4,6-Tribromophenol

68.3

76.8

80.8

72.3

Pesticides

Dibutylchlorendate

100

114

93

97

(a) Statement: All Surrogate recoveries are acceptable for low-level sojl contamination under CLP guidelines for laboratory data evaluations (EPA 1988) 
TABLE B.5. Mass Fractions of Sediment Grain Sizes

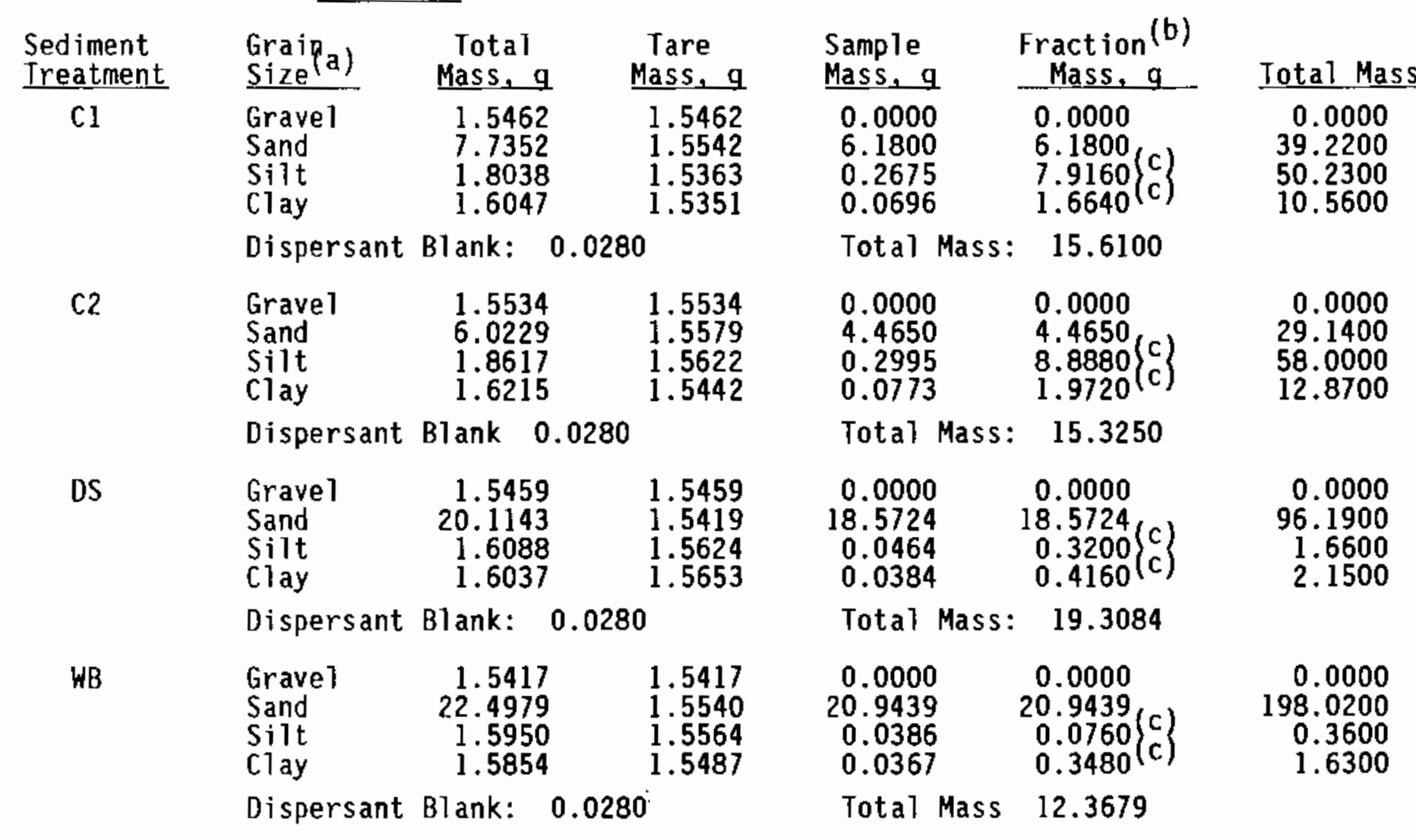

(a) By definition, gravel $>2.00 \mathrm{~mm}$, sand $=0.063$ to $2.00 \mathrm{~mm}$, silt $=0.004$ to $0.063 \mathrm{~mm}, \mathrm{clay}$ $<0.004 \mathrm{~mm}$.

(b) Fraction mass is the sample mass divided by the percent of total volume analyzed.

(c) Sample masses of silt and clay were multiplied by 40 to obtain fraction masses because samples of both were obtained from aliquots of $1 / 40$ of $1 \mathrm{~L}$ of suspended sediments.

However, fractions mass may not equal $40 x$ sample mass because of subtraction of clay mass from silt mass and correction for dissolved salts. 


\section{REFERENCE}

U.S. Environmental Protection Agency (EPA). 1988. Laboratory Data Validation: Functional Guidelines for Evaluating Organics Analyses. R-582-5-501, Hazardous Site Evaluation Division, Washington, D.C. 
APPENDIX $C$

IISSUE CHEMISTRY DATA SUMMARY 


\section{APPENDIX $C$}

\section{IISSUE CHEMISTRY DATA SUMMARY}

TABLE C.1. PAH Method Blanks for M. nasuta Tissues

\begin{tabular}{ll}
\multicolumn{2}{c}{ Method Blank, $\mu \mathrm{g} / \mathrm{kg}$} \\
\hline Naphthalene & $33 \mathrm{U}$ \\
2-Methylnaphthylene & $33 \mathrm{U}$ \\
2-Chloronaphthalene & $33 \mathrm{U}$ \\
Acenaphthylene & $33 \mathrm{U}$ \\
Acenaphthene & $33 \mathrm{U}$ \\
Dibenzofuron & $33 \mathrm{U}$ \\
Fluorene & $33 \mathrm{U}$ \\
Phenanthrene & $33 \mathrm{U}$ \\
Anthracene & $33 \mathrm{U}$ \\
Fluoranthene & $33 \mathrm{U}$ \\
Pyrene & $33 \mathrm{U}$ \\
Benzo(a)Anthracene & $33 \mathrm{U}$ \\
Chrysene & $33 \mathrm{U}$ \\
Benzo(B)Fluoranthene & $33 \mathrm{U}$ \\
Benzo(k)Fluoranthene & $33 \mathrm{U}$ \\
Benzo(a)Pyrene & $33 \mathrm{U}$ \\
Indeno(l, 2,3-cd)Pyrene & $33 \mathrm{U}$ \\
Dibenz(a, h)Anthracene & $33 \mathrm{U}$ \\
Benzo(ghi)Perylene & $33 \mathrm{U}$ \\
& \\
\hline
\end{tabular}

\begin{tabular}{lr} 
Surrogate Recoveries, $\%(a)$ \\
\hline 2-Flurobiphenyl & 97.1 \\
d14-p-Terphenyl & 83.7
\end{tabular}

$33 \mathrm{U}$

$33 \mathrm{U}$

330

330

330

$33 \mathrm{U}$

330

$33 \mathrm{U}$

330

330

$33 \mathrm{U}$

330

$33 \mathrm{U}$

(a) Surrogate recoveries are within allowable limits for acceptability based on EPA 1988. 
IABLE C.2. PAH Anaiytes Detected and Their Concentrations in $\underline{M}$. nasuta Tissues

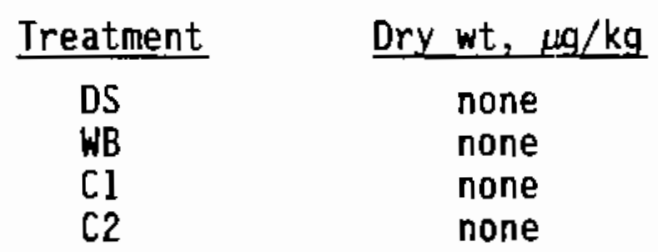

TABLE C.3. Pesticide/PCB Method Blanks for $\underline{M}$. nasuta Tissues Method Blanks, $\mu \mathrm{g} / \mathrm{kg}$

\begin{tabular}{ll}
\hline Alpha-BHC & $1.5 \mathrm{U}$ \\
Beta-BHC & $1.5 \mathrm{U}$ \\
Delta-BHC & $1.5 \mathrm{U}$ \\
Gamma-BHC (Lindane) & $1.5 \mathrm{U}$ \\
Heptachlor & $1.5 \mathrm{U}$ \\
Aldrin & $1.5 \mathrm{U}$ \\
Heptachlor Epoxide & $1.5 \mathrm{U}$ \\
Endosulfan I & $4.5 \mathrm{U}$ \\
Dieldrin & $3.0 \mathrm{U}$ \\
4,4' -DDE & $3.0 \mathrm{U}$ \\
Endrin & $3.0 \mathrm{U}$ \\
Endosulfan II & $3.0 \mathrm{U}$ \\
4,4' -DDD & $3.0 \mathrm{U}$ \\
Endosulfan Sulfate & $3.0 \mathrm{U}$ \\
4,4' DDT & $3.0 \mathrm{U}$ \\
Methoxychlor & $6.0 \mathrm{U}$ \\
Endrin Ketone & $3.0 \mathrm{U}$ \\
Gamma-Chlordane & $3.0 \mathrm{U}$ \\
Alpha-Chlordane & $3.0 \mathrm{U}$ \\
Toxaphene & $150 \mathrm{U}$ \\
Aroclor-1242/1016 & $20 \mathrm{U}$ \\
Aroclor-1248 & $20 \mathrm{U}$ \\
Aroclor-1254 & $20 \mathrm{U}$ \\
Aroclor-1250 & $20 \mathrm{U}$ \\
& \\
\hline
\end{tabular}
$\frac{\text { Pesticide Surrogate Recovery, \% (a) }}{\text { Dibutylchloroendate }}$ 104 
IABLE C.4. Pesticide/PCB Analytes Detected and Their Concentration in $\underline{M}$. nasuta Tissues and the Mean and Standard Deviation of Detected Values

\begin{tabular}{|c|c|c|c|c|c|c|c|c|}
\hline \multirow{3}{*}{$\frac{\text { Treatment }}{1}$} & \multirow[b]{2}{*}{ Analyte } & \multicolumn{5}{|c|}{ Tissue Concentration, $\mu \mathrm{g} / \mathrm{kg}$} & \multirow[b]{2}{*}{ Mean } & \multirow[b]{2}{*}{ SD } \\
\hline & & Rep 1 & Rep 2 & Rep 3 & & Rep 5 & & \\
\hline & $4,4^{\prime}-\mathrm{DDE}$ & $2.5 \mathrm{~J}$ & $2.1 \mathrm{~J}$ & $3 \mathrm{~J}$ & $1.6 \mathrm{~J}$ & $2 \mathrm{~J}$ & $2.025 \mathrm{~J}$ & $0.33 \mathrm{~J}$ \\
\hline & $4,4^{\prime}-\mathrm{DOD}$ & 14 & 12 & 4.5 & 6.2 & 8.2 & 8.98 & 3.96 \\
\hline & Aroclor -1254 & $13 \mathrm{~J}$ & $11 \mathrm{~J}$ & $6.3 \mathrm{~J}$ & $7.7 \mathrm{~J}$ & $11 \mathrm{~J}$ & $9.8 \mathrm{~J}$ & $2.73 \mathrm{~J}$ \\
\hline $\mathrm{C} 2$ & $4,4^{\prime}-\mathrm{DDE}$ & $2 \mathrm{~J}$ & $2.5 \mathrm{~J}$ & $1.5 \mathrm{~J}$ & $3 \mathrm{U}$ & $1.7 \mathrm{~J}$ & $1.925 \mathrm{~J}$ & $0.435 \mathrm{~J}$ \\
\hline & $4,4^{\prime}-\mathrm{DOD}$ & 12 & 6.2 & 4.2 & 4.4 & 8.3 & 7.02 & 3.24 \\
\hline & Aroclor-1254 & $13 \mathrm{~J}$ & $17 \mathrm{~J}$ & $10 \mathrm{~J}$ & $10 \mathrm{~J}$ & $11 \mathrm{~J}$ & $12.2 \mathrm{~J}$ & $2.95 \mathrm{~J}$ \\
\hline DS & $4,4^{\prime}-\mathrm{DDE}$ & $3 U$ & $3 \mathrm{U}$ & $3 \mathrm{U}$ & $3 \mathrm{U}$ & $3 v$ & & \\
\hline & $4,4^{\prime}-\mathrm{DDD}$ & $3 \mathrm{U}$ & $3 \mathrm{U}$ & $3 \mathrm{U}$ & $3 U$ & $3 \mathrm{U}$ & & \\
\hline & Aroclor- 1254 & $20 \mathrm{U}$ & $20 \mathrm{U}$ & $20 \mathrm{U}$ & $20 \mathrm{U}$ & $20 \mathrm{U}$ & & \\
\hline
\end{tabular}

U Indicates compound was not detected at given detection 1 imit.

$\mathrm{J}$ Indicates measured below calculated detection limit but considered real by the analyst. 
IABLE C.5. Concentrations of Selected Metals in the Tissues of M. nasuta after 20 Days of Exposure to Sediment Treatments

\begin{tabular}{|c|c|c|c|c|c|c|}
\hline \multirow[b]{2}{*}{ Ireatment } & \multirow[b]{2}{*}{ Rep } & \multicolumn{5}{|c|}{ Tissue Concentrations, $\mu \mathrm{g} / \mathrm{g}$ dry weight } \\
\hline & & $\mathrm{Zn}$ & $\mathrm{Ha}$ & $\mathrm{Cu}$ & $\mathrm{Pb}$ & $\ldots c d$ \\
\hline \multirow[t]{5}{*}{$\mathrm{Cl}$} & 1 & 131.7 & 0.092 & 20.19 & 1.49 & 0.21 \\
\hline & 2 & 123.9 & 0.107 & 16.86 & 1.59 & 0.31 \\
\hline & 3 & 96.9 & 0.071 & 18.07 & 1.26 & 0.16 \\
\hline & 4 & 141.1 & 0.097 & 40.74 & 2.58 & 0.21 \\
\hline & 5 & 118.8 & 0.071 & 31.83 & 2.96 & 0.26 \\
\hline \multirow[t]{5}{*}{ C2 } & 1 & 106.2 & 0.067 & 20.63 & 1.21 & 0.26 \\
\hline & 2 & 131.9 & 0.093 & 26.29 & 1.48 & 0.21 \\
\hline & 3 & 140.9 & 0.060 & 16.90 & 0.99 & 0.21 \\
\hline & 4 & 150.3 & 0.066 & 22.75 & 1.14 & 0.27 \\
\hline & 5 & 130.7 & 0.071 & 19.04 & 0.86 & 0.31 \\
\hline \multirow[t]{5}{*}{ DS } & 1 & 120.9 & 0.058 & 13.69 & 1.80 & 0.31 \\
\hline & 2 & 109.6 & 0.072 & 23.32 & 1.71 & 0.31 \\
\hline & 3 & 116.4 & 0.079 & 18.33 & 2.38 & 0.21 \\
\hline & 4 & 190.2 & 0.069 & 17.58 & 1.54 & 0.31 \\
\hline & 5 & 130.8 & 0.065 & 18.80 & 1.48 & 0.31 \\
\hline
\end{tabular}

\section{REFERENCE}

U.S. Environmenta1 Protection Agency (EPA). 1988. Laboratory Data Validation: Functional Guidelines for Evaluating Organics Analyses. R-582-5-501, Hazardous Site Evaluation Division, Washington, D.C. 
APPENDIX D

CALIBRATION SCHEDULES 
APPENDIX D

\title{
CALIBRATION SCHEDULES
}

\author{
Analysis: $\quad$ Organics and Pesticides \\ Performed at: Analytical Resources, Inc. (ARI) \\ Seattle, Washington \\ Equipment: Hewlett-Packard 5890 Gas Chromatograph \\ Hewlett-Packard 7673-A Autosampler \\ Hewlett-Packard 3392-A Sample Integrator \\ Hewlett-Packard 3393-A Sample Integrator \\ Capillary column equipped with two electron capture \\ detectors \\ Finnigan Model 4000 Mass Spectrophotometer \\ Finnigan INCOS Beta System \\ Hewlett-Packard 5790 Gas Chromatograph \\ Calibration \\ Daily calibration was performed by ARI personnel using U.S. \\ Information: EPA Contract Lab Protocol (CLP). Performance checks were \\ conducted with standard reference materials (SRMs) by ARI \\ personnel before the series was run. \\ Maintenance Maintenance by ARI or Hewiett-Packard personnel was \\ Information: performed routinely or when indicated by performance \\ checks. \\ Sample Tracking: All analysis were tied to specific machine and operator via \\ sample tracking form used by ARI. \\ Responsible \\ $\operatorname{Person}(s)$ : \\ Dave Mitche11
}

D. 1 
Analysis: $\quad$ Arsenic, Copper, Chromium, Nickel, Mercury, Cadmium, Lead, and Zinc

Performed at: Battelle/MSL

Sequim, Washington

Equipment: House Built Atomic Fluorescence Spectrophotometer (mercury)

Perkin-Elmer 5000 Atomic Absorption

Spectrophotometer (cadmium, arsenic, chromium, nicke), and lead) (S/N 5016)

Instrumentation Laboratory 251

Flame Atomic Absorption Spectrophotometer (\#1277) (copper and $z$ inc)

Calibration

Information:

Al1 instruments were calibrated daily with SRMs.

Maintenance

Maintenance was performed by Bottelie or authorized

Information: technical representatives as needed, or when indicated by calibration results.

Sample Tracking: All analyses were tied to specific machine and operator via Battelle's laboratory book system. All data were approved by $E$. A. Crecelius (Battelle/MSL).

Responsible

$\operatorname{Person}(\mathrm{s})$ :

E. A. Crecelius, C. W. Apts, and 0. A. Cotter 

Analysis: Grain Size
Performed at: Battelle/MSL
Sequim, Washington
Equipment: Tyler Standard Sieves
Mettler AC-100 Analytical Balance (S/N A89515)
Calibration The Mettler analytical balance is calibrated annualiy by
Information: Quality Control Services, Portland, Oregon.
Maintenance The Mettler analytical balance is maintained annually by
Information: Quality Control Services, Portland, Oregon.
Sample Tracking: All analyses were tied to specific balance and analyst via Battelle's laboratory book system. Ail data were approved by E. A. Crecelius (Battelle/MSL).

Responsible

Person(s):

E. A. Crecelius and 0. A. Cotter 
Analysis: $\quad$ Petroleum Hydrocarbon/0il and Greese

Performed at: AmTest, Inc.

Redmond, Washington

Equipment: $\quad$ Beckman Acculab 4 Infrared Spectrophotometer (S/N 1000009) Silca gel

Calibration

Equipment was Calibrated daily with EPA reference 0 il by

Information: Battelle/MSL personnel.

Maintenance

Maintenance was performed by AmTest or Beckman personnel as Information: needed, or when indicated by calibration results.

Sample Tracking: All analyses were tied to specific machine and operator via Iaboratory book system approved by AmTest and verified by John Dailey.

Responsible

$\operatorname{Person}(s)$ :

John Dailey 


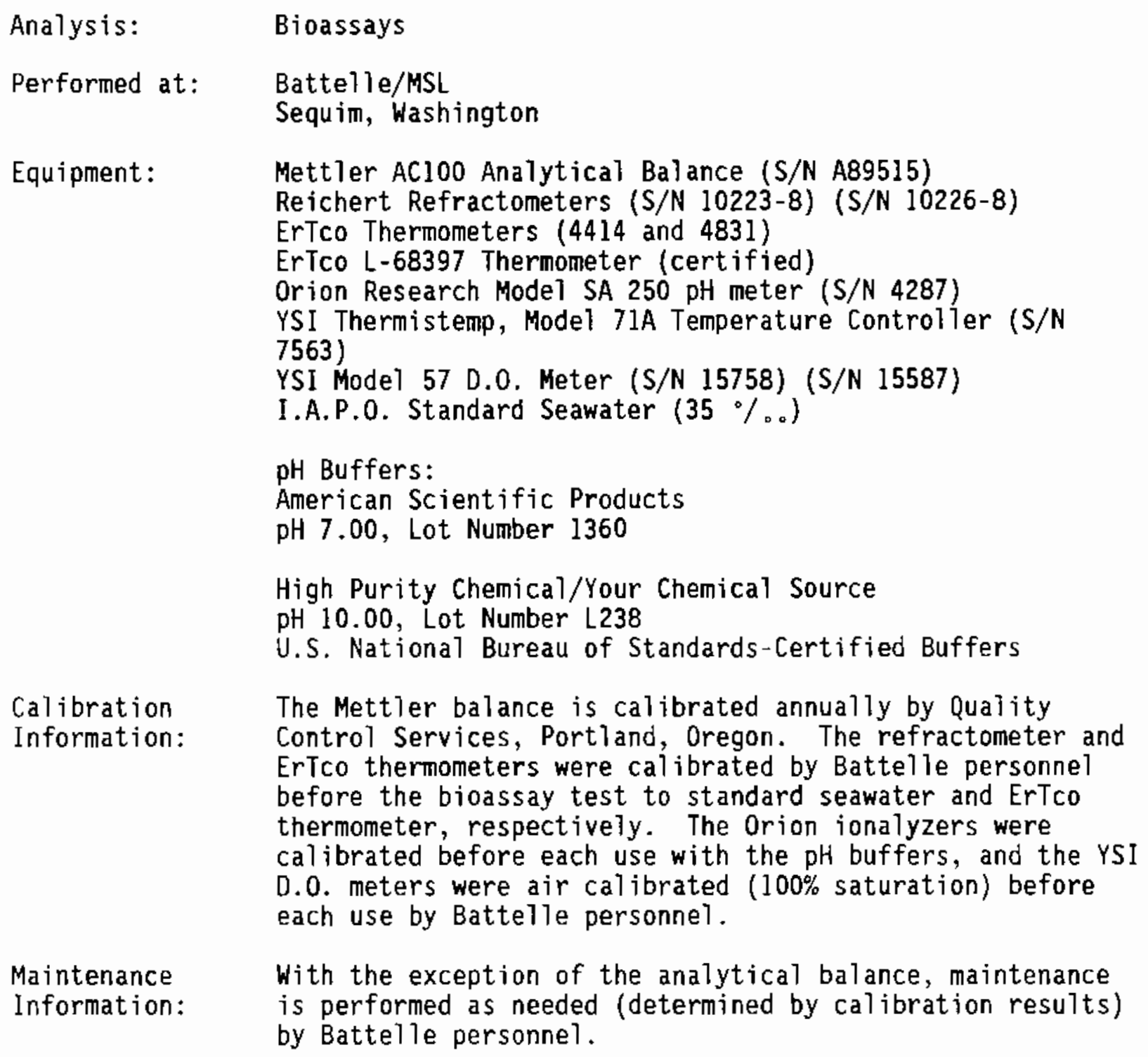

Maintenance With the exception of the analytical balance, maintenance Information: is performed as needed (determined by calibration results) by Battelle personnel.

Sample Tracking: All measurements were tied to the specific instrument and analyst via Battelle's laboratory book system. All data were approved by J. Q. Word (Battelle/MSL).

Responsible

Person(s):

J. Q. Word and J. S. Young 
Analysis: $\quad$ Total Organic Carbon (TOC)

Performed at: Global Geochemistry Corporation

Canoga Park, California

Equipment: Leco Induction Furnace

Model $521000(S / N 4260)$ with a carbon determinator

Calibration Calibration performed daily with standard materials by

Information: Global Geochemistry personne].

Maintenance Maintenance performed as needecl by G10bal Geochemistry

Information: personne1.

Sample Tracking: All analyses, were tied to specific machine operator via laboratory book system approvec by Global Geochemistry and verified by Kelly Dunnahoo.

Responsible

Person(s):

Kel1y Dunnahoo 


\section{DISTRIBUTION}

No. of

Copies

OFFSITE

M. E. Barrows

27 Compass Circle

Hyannis, MA 02601

25 R. Turner

Portland District

U.S. Army Corps of Engineers

Multnomah Building

319 S.W. Pine

Portland, OR 97208

2 DOE/Office of Scientific and Technica? Information

6 Battelle/Marine Sciences Laboratory

C. W. Apts

V. I. Cullinan

E. A. Crecelius

R. M. Ecker

N. P. Kohn

J. Q. Word
No. of

Copies

ONSITE

21 Pacific Northwest Laboratory

J. W. Falco

M. J. Graham

J. M. Hales

P. C. Hays

D. W. Johnson

J. A. Stottlemyre

J. R. Weber

R. E. Wildung

J. S. Young (6)

Publishing Coordination (2)

Technical Report Files (5) 
,

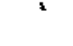

